\title{
On the Optimal Assignment of Competences in a Multi-Level Governed European Union
}

\begin{tabular}{|c|}
\hline \hline Fritz Breuss and Markus Eller \\
\hline \hline European Integration online Papers (EIoP) Vol. 7 (2003) $\mathrm{N}^{\circ}$ 8; \\
http://eiop.or.at/eiop/texte/2003-008a.htm \\
Date of publication in the EIOP $: 11.9 .2003$ \\
\hline \hline $\mid$ Full text $\mid$ Back to homepage $\mid$ PDF $\mid$ \\
$\mid$ This paper's comments page $\mid$ Send your comment! to this paper |
\end{tabular}

\section{Keywords}

federalism, fiscal federalism, decentralisation, economic integration, constitutional economics, competences, European Convention

Abstract

This paper surveys the theoretical and empirical research on the efficient assignment of policy tasks to different levels of government and applies the results on the delimitation of competences within the European Union. The main results are: (i) A precise derivation of an optimal degree of decentralisation is not possible because of mixed theoretical suggestions. The adequate degree of decentralisation has to be detected case-by-case. (ii) Systematic evidence on direct relationships between economic performance and fiscal decentralisation is ambiguous and scarce. (iii) Comparing the actual and prospective delimitation of EU-competences with the normative recommendations, remarkable discrepancies arise in the fields of agriculture and defence. (iv) The establishment of a flexible assignment-scheme is an undeniable necessity in order to guarantee reversibility and to cope efficiently with changing general conditions. In this respect, the European Convention has delivered insufficient results in its final draft Treaty as of July 2003.

\begin{tabular}{l} 
Kurzfassung \\
\hline \hline Dieser Artikel fasst die aktuelle theoretische und empirische Literatur zur effizienten Zuordnung \\
öffentlicher Aufgaben auf verschiedene Regierungsebenen zusammen und wendet die daraus \\
resultierenden Erkenntnisse auf die Kompetenzabgrenzungsdebatte innerhalb der Europäischen \\
Union an. Die wesentlichen Schlussfolgerungen lauten: (i) Die präzise Ableitung eines optimalen \\
Dezentralisierungsgrades ist aufgrund inkonsistenter und widersprüchlicher theoretischer Aussagen \\
nicht möglich. Der jeweils adäquate Dezentralisierungsgrad kann nur von Fall zu Fall abgewogen \\
und bestimmt werden. (ii) Der Zusammenhang zwischen ökonomischer Performance und fiskaler \\
Dezentralisierung weist keine systematische empirische Evidenz auf. Entsprechende \\
Untersuchungen sind uneindeutig und rar. (iii) Der Vergleich der aktuellen und zukünftigen \\
Dezentralisierung von EU-Politikfeldern mit den ökonomischen normativen Empfehlungen \\
offenbart deutliche Diskrepanzen bei Landwirtschaft (zu zentral angesiedelt) und Verteidigung (zu \\
dezentral angesiedelt). (iv) Die Entwicklung eines flexiblen Zuordnungsschemas ist eine \\
unabdingbare Notwendigkeit, um Reversibilität in der Kompetenzverteilung zu gewährleisten und \\
sich ändernden Rahmenbedingungen auf effiziente Weise Rechnung zu tragen. In diesem \\
Zusammenhang hat der Europäische Konvent leider unzureichende Ergebnisse in seinem \\
Endentwurf vom Juli 2003 geliefert.
\end{tabular}

\section{The authors}

Prof. Dr. Fritz Breuss is Professor at the Research Institute for European Affairs, University of Economics and Business Administration, Vienna and senior economist at the Austrian Institute of Economic Research (WIFO); email: Fritz.Breuss@wu-wien.ac.at; Homepages: http://fgr.wuwien.ac.at/institut/ef/cvbreuen.html and http://www.wifo.ac.at/Fritz.Breuss/; Markus Eller works as a Project Assistant at the Research Institute for European Affairs, University of Economics and Business Administration, Vienna; email: Markus.Eller@wu-wien.ac.at . 


\section{On the Optimal Assignment of Competences in a Multi-Level Governed European} Union $(*)$

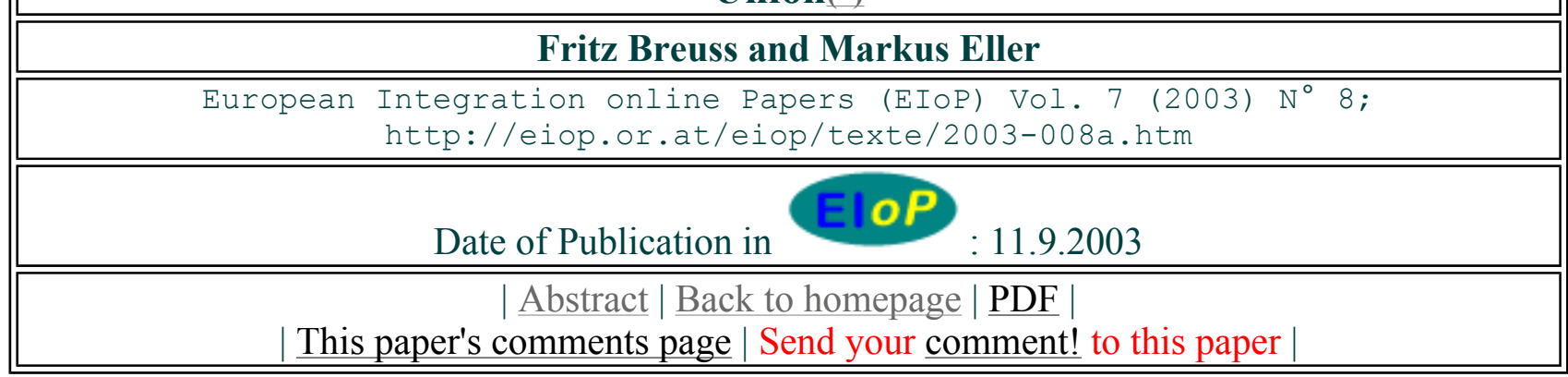

\section{Contents:}

- Introduction

- I Assignment of Policy Tasks to Different Levels of Government: Theoretical Survey

- 1.1 Theoretical Features of Fiscal Federalism

- 1.1.1 Optimal Consideration of Heterogeneous Regional Preferences

- 1.1.2 Realisation of Economics of Scale, Internalisation of External Effects

- 1.1.3 Inter-jurisdictional Competition, Division of Labour

- 1.1.4 Politico-Economic Variables

- 1.1.5 Geographical and Demographic Variables

- 1.2 The Basic Trade-Off and Derivation of an Optimal Degree of Decentralisation

- II Empirical Review

○ 2.1 The Data: Existing Decentralisation Indicators

- 2.2 Evidence from Empirical Studies

○ 2.3 Critical Appraisal

- III Application to the European Question: the Integration Process and Open Questions of an Appropriate Assignment of Policy Tasks

○ 3.1 Optimal Distribution of Competences within the EU: Normative Recommendations

- 3.2 Actual and Prospective Distribution of EU-Competences: Discussion within the

European Convention

○ 3.3 Comparison of Normative Recommendations With the Actual and Prospective

Distribution of Competences

- 3.4 Procedural and Institutional Suggestions

- IV Summary and Concluding Remarks

- References 


\section{Introduction $^{\uparrow}$}

"Although the protagonists of constitutional change couch their arguments mainly in the political language, economic issues have an immense underlying importance in determining the choice among different constitutional structures.” (Burrows, 1980: 45)

At present we can observe a certain "constitutional change" - or better, the development of a new Constitution - in Europe. The constitutional debate has been opened, at least politically, with the "Declaration on the Future of the Union" included in the Treaty of Nice, carried on with the "Laeken Declaration on the Future of the European Union" (15 December 2001), which poses the questions "[...] whether the simplification and reorganisation [of the Treaties] might not lead in the long run to the adoption of a constitutional text in the Union?" and "What might the basic features of such a constitution be?" Via the Laeken Declaration the European Council convenes a Convention, whose task it will be "to consider the key issues arising for the Union's future development and try to identify the various possible responses." This European Convention held its inaugural meeting on 28 February 2002. It has been working on the basic foundations of the future Constitutional Treaty since then. On 28 October 2002 Valéry Giscard d'Estaign, the Chairman of the European Convention, presented the Preliminary Draft Constitutional Treaty(1). Specific articles and protocols, as proposed for explicit inclusion into the final draft followed(2), basing mainly on the final reports of the European Convention working groups, which were instituted in order to examine different constitutional subject areas(3). On 10 July 2003 the Convention completed its work and on 18 July 2003 they submitted the final version of the "Draft Treaty establishing a Constitution for Europe"(4), adopted by consensus by the Convention on 13 June and 10 July 2003, to the president of the European Council in Rome(5).

As stated in the introductory quotation, this process does not only deserve analysis from a political or legal point of view, but also from an economic perspective. This paper highlights the economic implications of the constitutional process in the European Union (EU) and focuses its analysis mainly on the competence question: What's the optimal assignment of policy tasks to the different levels of government within the EU? How can the competences between the Union and the Member States be delimited optimally based on economic efficiency backgrounds? The assignment of policy tasks within the EU has to take into account "the dispersion of authority away from central government - upwards to the supranational level, downwards to sub-national jurisdictions and sideways to public/private networks" (Hooghe/Marks, 2001: 3). The concerning question of an optimal assignment is a multifaceted one and can only be answered satisfactory summarising the results of different research disciplines: economics, political science and law. Scholars of political economy, public choice theory, (fiscal) federalism, decentralisation, European integration, regional and global regimes or international relations provide meaningful conclusions for this question. The chosen literature refers to these different disciplines and leads us to a survey, which focuses on the one hand on the economic circumstances determining the allocation-question and constructs on the other hand linkages to the neighbour disciplines. From the economic point of view we concentrate our survey primarily on the insights of the theory of fiscal federalism. Allocative efficiency arguments come to the fore, while income redistribution or macroeconomic management are only analysed marginally. 
This paper is organised as follows: Section I reviews the theoretical economic literature developed with regard to the assignment-question since the pioneer publications of Charles M. Tiebout (1956), Wallace E. Oates (1972), and Richard A. Musgrave (1959) (so-called "TOM-Models"). Basic pro and cons of decentralisation are highlighted and the trade-off between centralisation and decentralisation decisions is consequently depicted. Section II reviews the current empirical evidence and provides a basis for further research and policy-making. Section III applies the insights of Section I and II to the actual constitutional process, compares the normative recommendations by function with the actual and prospective delimitation of competence and draws necessary procedural and institutional preconditions in order to guarantee an efficient and flexible assignment of policy tasks. Finally, Section IV concludes summarising the main results.

\section{Assignment of Policy Tasks to Different Levels of Government: Theoretical Survey ${ }^{\uparrow}$}

The theory of fiscal federalism or the economic theory of federalism, respectively, delivers crucial insights regarding the assignment-question. "The main analytical task of fiscal federalism has been to define the appropriate assignment of allocative responsibilities to decentralised government levels and matching revenue sources" (Bird et al., 2002: 416f). Summarising the basic theoretical insights of fiscal federalism, we are able to filter out five fundamental features, which are decisive for our assignment-question. These features, in turn, can be used as a kind of "checklist" in the case of concrete decentralisation or centralisation decisions. The surveyed literature discusses predominantly decentralisation objectives. But in the case of centralisation questions (e.g., dispersion of authority upwards from the Member States (MS) to the EU-level), the insights from the decentralisation debate can be mirrored.

\subsection{Theoretical Features of Fiscal Federalism ${ }^{\uparrow}$}

Many authors take the insights of the theory of public goods - namely the three famous "Musgravian branches" (Musgrave, 1959) of governmental economic functions (allocation, distribution and stabilisation) as a starting point in order to explain the functional responsibilities of different levels of government (e.g., Andersson/Hårsman/Quigley 1997, Hemming/Spahn 1997, Pehnelt 1999, Persson/Roland/Tabellini 1996, Vukovich 2000). The allocation branch is concerned with the production of goods and services for which competitive private markets fail to operate efficiently. Extending the theoretical facets of Samuelson (1954) regarding public goods to a spatial dimension, sub-national provision of pure public goods would be inefficient and can therefore be excluded (see Alesina/Angeloni/Schuknecht 2001, Eichenberger/Hosp 2001, Smekal 2001), whereas the provision of public goods, which are non-rivalry only at the local level, can be differentiated spatially (see Henke/Perschau 1999).

In this connection, the adequate degree of differentiation has to be detected. A lot of circumstances have to be taken into account, whereby the discussion of classical economists focuses primarily economies of scale (as a criterion in favour of a centralised provision) on the one hand and heterogeneity of local preferences (as a criterion in favour of a decentralised provision) on the other hand. Figure I depicts this basic contradiction and illustrates the difficult identification of the appropriate level of differentiation for each kind of activity. 
These two basic effects as well as three further main features, which determine from our point of view decisively the assignment-question, are filtered out from the existing literature as follows. In this regard, Table I operates as a "guiding map".

Figure 1

\subsubsection{Optimal Consideration of Heterogeneous Regional Preferences}

Referring to the two central theorems of Oates (1972) - namely the decentralisation theorem and the correspondence principle - the significance of heterogeneous preferences becomes clear. Let us follow the argumentation of Quigley (1997) and assume that all households in a given area must consume the same amounts of the goods, necessitating some compromise. With any diversity of needs among the population, a division into smaller groups of the population would likely result in less compromise among the citizenry. When population groups are smaller, the demands of any randomly chosen household will be closer to the demand of the average household in the group. Economic welfare will thus be improved, as the provision of services for each group is closer to each member household's optimum. Therefore, a uniform level of public services offered in each community is inappropriate. "Pareto efficiency can be raised through fiscal decentralisation" (Thießen, 2000: 5). Thus, governments should provide each public good including the respective set of individuals who consume the good: there is "perfect correspondence" in the provision of public goods (see Oates, 1972: 34). Or as Cremer/Estache/Seabright (1994: 5) put it, "each type of good should be provided by a level of government [...] enjoying a comparative advantage in accounting for the diversity of preferences in its choice of service delivery." To sum it up: a strong case in favour of decentralisation can be deduced from the consideration of the diversity of local preferences. However, meaningful critical remarks blur this clear recommendation.

It seems very unrealistic to possess the complete knowledge of the citizens' tastes - there appears the so-called "preference revelation problem" (see Hemming/Spahn, 1997: 111). Although central governments could efficiently provide local goods, they are too far distanced from local interests: high information, transaction, control or frustration costs are the consequences (see Zimmermann/Henke, 2001: 178ff.). The decentralisation of several competences would be the resultant suggestion. But information regarding the concrete preferences is also needed by localities - the preference revelation problem can only be solved introducing mobility of people into the Oates model. If public goods are financed by local taxes that reflect costs of provision, mobility between localities will provide the necessary information (see Tiebout, 1956).

A lot of factors accompanying the decentralisation process could offset to some extent the above delineated efficiency gains. One of them are "administrative weaknesses at the sub-national level, especially the lack of modern and transparent public expenditure management systems" (TerMinassian, 1997: 22). More of these "hampering" effects are included in the resting four determinants of our assignment-question. 


\subsubsection{Realisation of Economics of Scale, Internalisation of External Effects ${ }^{\uparrow}$}

The realisation of economics of scale (EoS) and the internalisation of external effects are the main decisive factors for the assignment of functional responsibilities to the central government level. We can observe that average costs can be reduced with increasing output quantities. This is an argument in favour of a central provision of such goods. However, dealing with public goods, decreasing as well as increasing (e.g., costs in congested urban areas) average cost functions can be detected when additional output is produced (see Smekal, 2001: 70). Furthermore, even in the case of decreasing costs the clear centralisation recommendation is blurred: information costs for local citizens, the lack of accommodativeness and near usage as well as control costs for the central level have to be taken into the assignment calculus. Therefore, we found more pertinent arguments in favour of centralisation by examining interregional spill-over effects. Consequently, central governments deal with inter-jurisdictional externalities (e.g., pollution abatement) and regulate natural monopolies based on national networks (e.g., telecommunications) while local governments tend to control activities that have a regional limited impact (e.g., aircraft noise, in-city transportation) (see Hemming/Spahn, 1997: 113). Coping with these externalities, different directions can be distinguished in the literature. On the one hand, the existence of interregional spill-overs does not necessarily require the dispersion of the respective competence upwards to the central level (as claimed, e.g., by Smekal 2001), moreover grants-in-aid, fiscal transfers or horizontal co-operation among sovereign jurisdictions are valuable tools in order to internalise the externalities (see Hemming/Spahn 1997, Pigou 1932, Quigley 1997, Zimmermann/Henke 2001). On the other hand, externalities arising from the provision of public goods vary immensely - from planet-wide in the case of global warming to local in the case of most city services. In order to internalise these multifaceted externalities, multi-level governance is demanded (see Hooghe/Marks 2001). In this regard, two different types of multi-level governance are detected (see Table I).

As far as there is chosen the co-operation among jurisdictions as a solution in order to internalise externalities, we can distinguish opposite views again. The ones have the opinion that co-operation can be tailored to specific functions and does not need a comprehensive regional approach (Hemming/Spahn, 1997: 113). A supranational government will only play a catalytic role in such arrangements. The others perceive remarkable negotiation and transaction costs in the case of interjurisdictional co-ordination (see Behnisch/Buettner/Stegarescu 2001, Färber 2001, Olson 1969 , Schneider/Wagner 2000, Thomas 1997), which could lead to welfare losses because of an unsatisfactory internalisation of the externalities. Inman and Rubinfeld (1992: 656) pointed out that public goods with significant cross-border externalities could be provided also by voluntary arrangements between member states. But - besides the fact that at a minimum, a central government administrative structure will be needed to enforce the arrangements - efficient provision should not be expected. This so-called "decentral policy failure" leads to a necessary condition regarding our centralisation decision: If the uncooperative behaviour of regions leads to worse results than the co-operative behaviour and this co-operation is not credible without centralisation (because of free-rider effects), then the assignment to the central level would be necessary (see Thomas, 1997: 168). This condition emblematises the famous principle of subsidiarity, which is inscribed in general terms in the Maastricht Treaty. As a result, "budgetary intervention at the Community level ought to be admitted only in the presence of cross-border externalities or economies of scale, which cannot be properly alleviated by a simple coordination between concerned national governments" (Bureau/Champsaur, 1992: 89). 


\subsubsection{Inter-jurisdictional Competition, Division of Labour ${ }^{\uparrow}$}

This third feature of fiscal federalism bears in mind the "benchmark-effect" of a multi-level structured government system. Decentralised systems strengthen political and organisational (bottom-up) innovations and enforce competition between the different authorities (see Eichenberger/Hosp, 2001: 90; Sinn, 2003; Smekal, 2001: 70). They can realise efficiency gains by utilising their comparative advantages (see Cremer/Estache/Seabright, 1994: 5) and by dividing labour efforts corresponding to the respective local resources.

While the previous arguments argue for a decentralised system, there can be found noteworthy arguments in the literature, which deal with negative effects of inter-jurisdictional competition. In the field of taxation, e.g., distorting effects of exorbitant tax competition are focused and confronted with the alternative of a (EU-wide) tax harmonisation (see Austrian Institute for Economic Research [WIFO] 1998, Baldwin/Krugman 2000, European Parliament 2001, Fuest/Huber 2001, Goodspeed 1999, Henke/Perschau 1999, Pitta e Cunha 2002, Sinn 1993). Tax competition combined with a high degree of inter-jurisdictional integration and mobility leads to an inefficient low taxation of capital, sub-optimal allocation of resources is the consequence. Furthermore, redistribution from immobile to mobile factors takes place and could possibly lead to an undersupply of public goods (see Henke/Perschau 1999). Segregation tendencies are another critical phenomena often quoted in the case of tax competition: persons with higher income flock to jurisdictions with low tax rates for high incomes and supersede persons with low incomes, what in turn could aggravate social disparities (see Zimmermann/Henke, 2001: 183; Pehnelt, 1999: 13).

Combining the internalisation of externalities (see feature 2) and the division of labour, the concept of "Functional Federalism" plays a crucial role. In 1999 Bruno Frey and Reiner Eichenberger designed the Model of Functional, Overlapping and Competing Jurisdictions (FOCJ): the number of jurisdictions is vast rather than limited; they are not aligned on just a few levels, but operate at diverse territorial scales; they are functionally specific rather than multi-task and flexible rather than fixed; they guarantee vast representative and direct-democratic rights to their citizens and levy own taxes (see Frey/Eichenberger 1999, Hooghe/Marks 2001)(6). On the one hand, FOCJs allow reactions on the technological developments that change the spatial characteristics of public goods over time (see Tanzi, 1995: 299), guarantee democratic control and fiscal equivalence(7) (see Eichenberger/Hosp, 2001: 100), cope with the correspondence principle of Oates (1972) and "are an institutional way to vary the size of the jurisdictions in order to minimize spillovers" (Frey/Eichenberger, 1999: 41). On the other hand, their establishment has to take organisational difficulties, economic costs (control, co-ordination, information, non-realised EoS) as well as a potential lack of transparency into account (see Smekal, 2001: 71; Thomas, 1997: 163f.). Regarding these inconsistencies, the challenge of an optimal distribution of competences cannot be simply satisfied establishing overlapping and task-specific jurisdictions; in fact, the optimal degree of decentralisation or centralisation, respectively, has to be detected for each policy task case-bycase. Nevertheless, in view of existing FOCJs and their increasing occurrence in many economies, we would not like to undermine the importance of the respective analysis. As Casella and Frey (1992: 645) emphasised: "even if an entire political system could not be organized solely through uni-dimensional clubs, still the role of these clubs should not be undervalued". 


\subsubsection{Politico-Economic Variables}

Persson et al. (1996) reinforce our attempt to include also the neighbour disciplines in the assignment-question by stressing the deficiencies of the classical "Pigovian" approach (TOMModels), where generalised second-best arguments related to incentive constraints on the policy formation process are typically ignored. They adopt a broader politico-economic approach that addresses the second best effects of centralisation, as well as its effects on coalition formation. "When allowing for political economy considerations, straightforward normative conclusions on the appropriate degree of centralisation are much more difficult to draw. The use of generalized second best arguments requires a case-by-case approach and careful empirical analysis." (Persson et al., 1996: 3). This conclusion explains on the one hand the hitherto neglect of these variables in economic analysis, but on the other hand the linkage to Section II of this paper is constructed, where the empirical insights - also regarding politico-economic variables - are reviewed.

Evaluating the pros and cons of decentralised government structures, political economists usually link their analysis to the behaviour of revenue-maximising governments, to the effects of political competition or to the qualitative improvements of democracy. Starting with the "fragmentation hypothesis" or "Leviathan restraint hypothesis" of Brennan/Buchanan (1980), political economists try to check the relationship between a fragmented political system and the size of the public sector (see Kirchgässner/Schaltegger, 2002, see also Table III): The connection between government expenditures and revenues is strengthened by the existence of a fragmented system (hint: interjurisdictional competition pressure due to migration tendencies), stricter budget discipline is effectuated and therefore a diminution of the size of the public sector can be expected. Thus, an oversupply of public goods and x-inefficiency in the public sector can be prevented (see Thießen, 2000: 8). These conclusions of political economists are based primarily on the "central policy failure"-theorem: imperfect information, rent-seeking politicians as well as lobbying-activities of interest groups characterise the so-called Leviathan-behaviour, which leads to a sub-optimal consideration of local preferences and hence to welfare losses. This influence of vested interests can only be weakened by the enforcement of the political responsibility of the government, what, in turn, can be reached satisfactory through decentralisation (see Thomas, 1997: 168ff.).

The augmentation of democracy through a federal system is a further argument in favour of decentralisation. On the one hand, the better consideration of local preferences and interjurisdictional competition lead to democracy improvements; on the other hand, federalism increases political information for citizens and transparency in public transactions, which reinforces moreover the proper functioning of democracy (see Eichenberger/Hosp, 2001: 90). Fiscal decentralisation (FD) enhances political autonomy, which in turn motivates participation at the local level (see Elbel/Yilmaz, 2002). However, there can also be found arguments in the politico-economic literature, which do not support the overall positive view of decentralised government systems. They are relying on corruption at the local level and on the quality of governments. Following Prud'homme (1994), local elites are closer to people and hence more susceptible to personalism. They get improved access to public resources via decentralisation, what increases opportunities for corruption (see Tanzi, 1995: 301). Wildasin (1995) is more careful regarding this proposition: "There may be a trade-off between local corruption on a small scale and central corruption on a large scale. It seems impossible to say a priori which would dominate the other." (Wildasin, 1995: 327). Fact is, that recent empirical attempts at settling this question have so far given inconsistent results: Treisman (2000) does not find any significant relationship between fiscal decentralisation and corruption (see Dabla-Norris/Wade, 2002: 4), while in the cross-country regressions of Fisman/Gatti (2000) fiscal decentralisation appears to have a negative and significant effect on corruption (see Table III). 
Concerning the quality of governments, we have to bear in mind the trade-off between the local knowledge of the sub-national levels and the overall competence of the central level (see Andersson et al., 1997: 98f.). While the central level exhibits quality deficiencies because of scarce local knowledge, it may attract more qualified people because of better career opportunities and salaries and could therefore achieve a higher quality level (see Prud'homme, 1994; Thießen, 2000: 11). One the one hand, a scarcity of local talents could be the consequence and impede decentralisation efforts. On the other hand, "decentralized political institutions play an important role in developing skilled public administrators by allowing more widespread and direct participation in the affairs of government." (Oates, 1995: 351). Thus, it is difficult to give a clear recommendation to our assignment-question because of bureaucratic quality reasons. Again, a case-by-case approach is necessary.

\subsubsection{Geographical and Demographic Variables}

We have just stressed the quality of governments and the stock of human capital as meaningful determinants regarding the optimal assignment of policy tasks - now we proceed with further inherent characteristics of the different jurisdictions, namely with geographical variables. The size of the jurisdiction (and/or its population) is a decisive factor in order to evaluate the heterogeneity of preferences as well as the potential realisation of economies of scale. We could assume a strong relationship between the heterogeneity of preferences and the geographical distance between different jurisdictions (see Alesina/Perotti/Spolaore, 1995: 754; Färber, 2001: 112). The smaller the jurisdiction, the more homogenous are individual views, reducing the pronouncement of individual preferences: a decentralised structure cannot easily develop its benefits (see Thießen, 2000: 12). Moreover, "small countries should be more successful than large countries in satisfying the social needs of their population. [...] there would be strong reasons for breaking up countries and weaker reasons for fiscal decentralization." (Tanzi, 2000: 2). Thus, bearing in mind the discussion on FOCJs, essential tensions exist between the geographical demarcation of a jurisdiction and the decentralisation within a given limited geographical area.

The degree of urbanisation is another important geographical factor, which determines decentralisation decisions with regard to the diversification of the tax base and/or the functioning of democratic control. Tax bases are more diversified and democratic control is improved in the case of a high share of urban governments, decentralisation is consequently facilitated (see Prud'homme, 1995: 359; Thießen, 2000: 13).

Beside these two factors, the surveyed authors discuss ethnic fractionalisation, population density, accessibility of natural resources or historical circumstances as further variables, which have meaningful consequences for the assignment-question.

\subsection{The Basic Trade-Off and Derivation of an Optimal Degree of Decentralisation ${ }^{\uparrow}$}

Figure I demonstrates the difficult derivation of an optimal degree of decentralisation because of opposing tensions, which we have described feature-by-feature in Table I. It becomes clear that the basic trade-off between the realisation of scale effects and the internalisation of externalities, on the one hand, and the consideration of local preferences, on the other hand, creates meaningful tensions, which hamper clear recommendations for the practical assignment of policy tasks. Additionally, inter-jurisdictional competition, politico-economic variables, as well as geographical and demographic general conditions affect these normative assignment recommendations. 
Table I summarises the respective results of various authors and assigns them to the five analysed theoretical features. Apart from mixed suggestions of the reviewed authors within these features, pros and cons of a decentralised (or a centralised) government structure are more or less balanced. In this respect, a differentiated case-by-case examination is the only possible solution in order to get satisfactory recommendations for effective assignment problems. Section III picks this case-by-case approach up and tries to give policy-specific normative recommendations regarding the optimal assignment to different levels of government.

\section{Table 1}

\section{Empirical Review ${ }^{\uparrow}$}

In the light of the fact that the described theoretical trade-off impedes the derivation of clear and precise recommendations concerning the optimal degree and the effects of decentralisation, empirical analysis gets a crucial role. In this connection we have to question where we can find appropriate data sources, how the degree of decentralisation can be measured and which measure is the most suitable one. By identifying the degree of decentralisation within certain competence fields, we can subsequently describe the distribution of competences between different levels of government (see Table IV), what is our aim in order to provide normative recommendations for the EU. In this Section, Table III works as the guiding map and summarises empirical evidence.

\subsection{The Data: Existing Decentralisation Indicators ${ }^{\uparrow}$}

We can distinguish three different approaches in the reviewed literature with regard to the measurement of decentralisation. First, they work output-oriented and count the number of legal, judiciary and other non-binding acts ("policy acts") per government level.

Alesina/Angeloni/Schuknecht (2001) choose this new interdisciplinary approach, measure the intensity of the EU in policy-making and develop a certain de facto distribution of competences within the EU. This remarkable result has to be appraised critically: simple quantitative counting of each act does not necessarily inform about its effective impact on the respective policy chapter; the relative importance of EU's policy involvement cannot be examined, when the respective intensity measures of national and sub-national levels are not considered and, finally, the chosen data base CELEX $(8)$ does not inform how many acts are produced within a certain period - inter-temporal comparisons are not possible (see Von Bogdandy/Bast/Arndt, 2002: 85).

Second, they work input-oriented and measure the distribution of competences via input costs of those institutions, which are involved in the execution of the several policy areas and located on diverse government levels. Kramer (2000) follows this concept and examines the public personnel costs in Austria, Germany and Switzerland according to different fields of public functions and different government levels. One could conclude that a certain policy area is more decentralised the higher is the sub-national government's share of personnel costs in GDP. But this reasoning is blurred on the one hand by difficult methodical selections of different policy patterns in order to retain comparability between various levels of government and between several nation states (see Kramer, 2000: 27ff.). On the other hand the level of disaggregated personnel costs does not necessarily mirror the real distribution of competences because of diverse salary-structures according to different qualification prerequisites (see the discussion on the quality of governments in Chapter 1.1.4). 
Third, they refer to budget data and approximate the degree of decentralisation using the subnational government's (SNG) share of total public expenditures or revenues, respectively, and distinct between different policy chapters (see Elbel/Yilmaz 2002, Hoeller/Louppe/Vergriete 1996, Letelier 2001, Osterkamp/Eller 2003a and 2003b, Oates 1995, Thießen 2000). These indicators are used in most empirical papers. There seems to be consensus that the share of expenditures of subnational governments in consolidated government expenditures is the best proxy for the degree of decentralisation. Additionally, self-reliance ratios (share of own revenues of lower levels in their total revenues) and vertical imbalance ratios (intergovernmental transfers as a share of sub-national expenditures) are constructed, in order to examine the independence of sub-national levels. In this context, the Government Finance Statistics (GFS) of the International Monetary Fund (IMF) operate as the data base chosen by most authors(9). The World Bank evaluates the application of the GFS on decentralisation issues (e.g., the lack of details on expenditure autonomy and own-source revenue, deficiencies regarding reported data for the sub-national levels, information scarcity for analysing dispersion among sub-national regions), provides a broad decentralisation-bibliography and discusses thoroughly the measurement and adaptability of quantitative as well as qualitative fiscal decentralisation indicators (http://www1.worldbank.org/publicsector/decentralization ).(10)

\subsection{Evidence from Empirical Studies ${ }^{\uparrow}$}

\section{a) Fiscal Decentralisation of Government Activity}

Osterkamp and Eller (2003a) complied with the aforementioned concept of measuring fiscal decentralisation. They analysed total government expenditures of 19 OECD countries (plus Russia) and asked for the share which is spent by sub-central levels of government. This share is then looked at for its development over time. The degree of decentralisation differs widely between the sample. Sub-national tiers of federal countries spend on average more and rely less on central revenues to support their expenditures than unitary ones. Exceptions are the Scandinavian countries (unitary, but high degree of decentralisation) and Belgium (federal, but low degree of decentralisation). Over the past 30 years the share of sub-national levels in general government expenditures has not fluctuated remarkably, nor is there a visible trend. Nevertheless, the article shows considerable structural breaks in France, Norway and Spain.

A second study of Osterkamp and Eller (2003b) decomposes this general degree of decentralisation by different types of government expenditures(11) and constructs function-specific decentralisation ratios. The policy fields recreation, culture, religious affairs, housing and community amenities, education, transportation and communication, as well as public order and safety showed the highest functional decentralisation degrees. Even countries which show low general degrees of decentralisation, like France or Luxembourg, exhibit a high decentralisation ratio in these policy fields. Federal countries, on average, exhibit in each of the different fields of activity higher decentralisation degrees than the average of the unitary countries. In the fields of agriculture, public order and education, these differences are specifically pronounced. Asking additionally how the subcentral expenditures are distributed over the different expenditure categories, the article shows that sub-central spending is heavily concentrated on education, social security, health, and housing. 


\section{b) The Impact of Fiscal Decentralisation on Macroeconomic Indicators}

Several relationships between the degree of FD and macroeconomic indicators are examined in order to test the performance of a decentralised country. These examinations lead to possible answers whether the country could increase its economic performance by centralising or decentralising different policy tasks. Especially the linkages between economic growth and the size of the public sector, on the one hand, and the degree of FD, on the other hand, are focused within empirical analysis. It should be stated, that "there is no formalized theory of the relationship between fiscal decentralisation and economic growth" (Thießen, 2000: 5). That could really hamper the construction of valuable models and the delivery of satisfactory results. Nevertheless, researchers have put forward the following three hypotheses concerning the relationship between decentralisation and growth: In each of these hypotheses, growth has only a secondary relationship to decentralisation and the nature of this connection - growth-enhancing, growth-impeding, or growth-requiring - depends on what one sees as the primary effects of decentralisation. These primary effects, in turn, have much to do with the specific design of decentralisation policy.

\section{Table 2}

The few empirical studies, which have directly examined the relationship between decentralisation and growth, come up with ambiguous results. While Oates (1995) detects a significant and robust positive correlation between FD and growth, Davoodi and Zou (1998) find that decentralisation has a negative relationship to growth in low developed countries (LDCs) and OECD-countries. Observing the impacts on growth from the opposite point of view - namely from the centralisation perspective - the results are still mixed: while Behnisch/Buettner/Stegarescu (2001) identify a statistically significant positive effect of overall centralisation on TFP growth in Germany, Schneider and Wagner (2000) find that centralised wage bargaining shows a significant negative impact on longterm economic growth in the EU. On the one hand these contradictory results can be explained by different methodological approaches and the diverse designs for decentralisation chosen by the authors. On the other hand, the basic theoretical trade-off regarding our assignment-question, worked out in Section I, is in that way confirmed by empirical evidence. Accordingly, the analysis of Thießen (2000) suggests a hump-shaped relationship between growth and FD (see Figure II). In the case of too much decentralisation inter-jurisdictional externalities cannot be internalised and EoS are not realised; negative growth effects are the consequence. The same holds for a low level of decentralisation: unconsidered preferences lead to inefficiencies in the provision of public goods, what inhibits, in turn, economic growth.

\section{Figure 2}

Bearing the fragmentation hypothesis of Chapter 1.1.4 in mind, we have a strong theoretical argument in favour of a decentralised structure, which strengthens fiscal equivalence and institutional competition, what in turn has limiting effects on the size of the public sector. This hypothesis has been analysed empirically by many authors in the 1980ies (see Table III).

Kirchgässner (2001) reviews their results and concludes that there exists only fragile empirical evidence that fiscal federalism really limits the size of the public sector. This fact can be explained by higher requests of citizens, unrealised scale effects or by an excessive burden to the tax base due to decentralisation (see Kirchgässner/Schaltegger, 2002). These "costs" of a federal government structure are reflected also by the impact of FD on the central government deficit. An increasing effect can be detected, especially in the short run (see Fornasari/Webb/Zou, 1999). 
Conversely, this impact disappears in the long run, what can be interpreted as follows: when a process of FD is in progress, budget costs arise because of the shift of competences to new authorities and the implementation of new institutions. But bit-by-bit, the efficiency-enhancing effects of decentralisation gain ground, learning effects take place and the initial budget shock loses weight. However, we have to take into account that efficiency gains due to decentralisation can differ remarkably among different policy areas. Each competence field exhibits a diverse structure of local preferences, externalities, institutional competition opportunities and political decision-making. Empirical analysis has so far given little attention to these different structural components and studies regarding particular competence areas are scarce. In this context, competence-specific analysis puts its focus mainly on education and health. E.g., Letelier (2001) examines the impact of FD on the efficiency of education and public health via data envelopment analysis (DEA). He concludes that the efficiency of education is improved significantly by FD, while the quality of public health is improved to a less robust degree. As respects the politico-economic variables, we found empirical studies regarding corruption and "good governance". The former have just been stressed in Chapter 1.1.4. As respects the latter, Huther and Shah (1998) construct an index of good governance, which contains elements of citizen participation, government orientation, social development and economic management. FD has been used as an explanatory variable for this index. A significant and strong impact of FD on good governance can be found. Again, the theoretical positive effect of a federal structure on the quality of government and on the augmentation of democracy is confirmed.

\subsection{Critical Appraisal}

Despite the intense theoretical debate of the pro and cons of FD "systematic evidence on the contribution of FD to economic performance is scarce" (Oates, 1995: 352). Ambivalent effects are on work, clear recommendations regarding the optimal degree of decentralisation are difficult to draw. This Section showed that there is no unambiguous, automatic, relationship between decentralisation and growth. A return to the literature on decentralisation's primary effects may be a more useful way to think about this connection $(12)$. What really matters is the adequate design of decentralisation. It is necessary to examine reliable and comparable indicators for federal autonomies. Nowadays there is a lack of thorough cross-country econometric verifications. International comparisons, which modulate the different costs and benefits (e.g., by following the five central features developed in Section I), could provide a clearer advice regarding the respective federal structure and the optimal degree of decentralisation (see also Eichenberger/Hosp, 2001: 88). Furthermore, it is indispensable to extend the prevalent budget data approach by additional methods: two of them are discussed in Chapter 2.1, further ones can be found in the literature of political science and law(13). In order to cope with a multi-level government, the exploration of alternative approaches gets a crucial role, because "FD can be observed to have a significant effect on a wider range of variables" (Letelier, 2001: 8). Finally, this empirical survey should not only accentuate the extension of the samples and methods, but also endorse long-term analyses. 


\section{Application to the European Question: the Integration Process and Open Questions of an Appropriate Assignment of Policy Tasks}

Theoretical features of fiscal federalism are multifaceted and opposing, empirical suggestions are ambiguous and policy-specific evidence is scarce. In the light of these facts, this Section is confronted with the special challenge to construct the bridge between general advice regarding the optimal degree of decentralisation and the EU-specific assignment of policy tasks to its different tiers of government.

\subsection{Optimal Distribution of Competences within the EU: Normative Recommendations $\uparrow$}

As we have seen in Section I and II, the benefits and costs of central versus decentralised functional responsibility describe the trade-off within the cost-benefit-calculus of the vertical division of labour in federal entities (see Thomas, 1997: 162). Applying the previous surveyed theoretical and empirical background on the vertical division of labour (i.e., distribution of competences) within the EU, we can draw a rough picture of an optimal assignment of public services to the various types of authorities. Factors such as economies of scale, economies of scope, cost/benefit spill-overs, proximity to beneficiaries, consumer preferences, or flexibility in budgetary choices on the composition of spending, influence these normative recommendations illustrated in Table IV. As respects the competence-specific normative assignment, economists pick the basic trade-off discussed in Section I up and concentrate their examination mainly on spill-overs, economies of scale and on the structure of local preferences. Politico-economic or geographical variables play an inferior role. Although these variables should enter the ex ante calculus, they can be applied to the analysis of discrepancies between the effective distribution and the normative recommendations (see Chapter 3.3). Different policy domains are distinguished and the respective assignmentrecommendations of economists are reviewed in Table IV. These recommendations rely on the theoretical features we handled in Section I but also on empirical research. Concerning the delimitation of the chosen functions between the central (EU), the national (Member States) and the sub-national (states, regions, provinces, municipalities) levels, we can sum up meaningful interpretations from this table.

First, the predominant assignment of responsibilities to the EU-level is relatively clear within the areas of external trade, common market, competition policy, monetary policy, defence, foreign affairs, interstate transport and telecommunications. In these areas a provision by the central European level generates normatively higher allocative efficiency because of EoS-realisation, internalisation of externalities, homogeneity of preferences, harmonisation of divergent and distorting national regulations, or avoidance of free-rider effects. Characteristics of pure public goods are detected within these policy areas - sub-central provision of such goods would be inefficient and can therefore be excluded (see Chapter 1.1). Nevertheless, the recommendation of an overall responsibility of the EU does not hold even in these policy areas. According to Anwar Shah (2002: 576) we have to distinguish between different functions of policy responsibility, which could be met by only one level, shared by different levels of government or fulfilled also by nongovernment sectors. He distinguishes a) policy setting and control, b) provision and administration, c) production and distribution. In the case of external trade, for instance, the policy setting function should only be met by the supranational level, the functions of provision and administration should be shared by supranational, national as well as state/provincial governments; non-government sectors could take care of production and distribution. 
Other exceptions from the unambiguous assignment of the aforementioned policy tasks to the EUlevel exist in the area of common market, where exaggerated harmonisation could hamper free-areawide competition (see Alesina et al., 2001: 6) - and in the area of defence, where Shah (2002) classifies benefits and costs (arising from externalities and EoS) only national in scope.

Second, we can filter out policy areas, where the responsibility should be assigned primarily to the national and/or to the sub-national government. As regards industry, energy or agriculture, the assignment to the national level is explicitly recommended. In this context, the authors do not refer as usual on spill-over or preference views, but on pragmatic arguments. In the case of agriculture, Hoeller et al. (1996: 29) do not see any rationale for pursuing agricultural policy at the EU-level because of moves towards greater reliance on market forces. Sectoral policies could provide public goods, for example, if they support an EU-wide transportation and communication network. However, Alesina et al. (2001) cannot detect such a provision of public goods by the mentioned policy areas. Even, they see the danger, that these policies (in particular energy) could delay the completion of the internal market, when assigned to the EU-level.

Third, there exist a group of competences, where the assignment to only one level of government is not optimal. Environment is such a policy field, where the responsibility should be shared between different levels. On the one hand, scale effects as well as the setting of EU-wide environmental standards in order to avoid distortions of competition require a meaningful involvement of the Union (see Sinn, 2003). According to Bureau and Champsaur (1992: 89), competition distortion constitutes the main externality justifying a corrective centralised intervention. On the other hand, various externalities take effect on different levels and their influence is likely to be limited on the respective jurisdictional size, what, in turn, calls for a decentralised execution. Thus, the specification of the extent to which this function should be shared between the different levels could be difficult. A widespread examination is necessary.

Fourth, there remain policy chapters where the optimal assignment is discussed contradictorily by the various authors, depending on the research focus they have chosen. Education and research, on the one hand, and social policy, on the other hand, are such examples. In the former case, the ones found remarkable arguments for a decentralised assignment: consideration of heterogeneous local preferences, effects of inter-jurisdictional competition, or limited cross-national externalities (see Alesina et al. 2001, Smekal 2001, Persson et al. 1996). The others, in turn, depict strong reasons in favour of an assignment to the central European level: adverse effects of sub-national provision on the stock of human capital (Ter-Minassian, 1997), avoidance of R\&D-duplication (Hoeller et al., 1996), or increase of EU-wide labour mobility due to enforced teaching of European subjects (Persson et al., 1996). As respects social policy, local preferences and inter-jurisdictional competition are stated as arguments in favour of decentralisation again (Alesina et al. 2001, Smekal 2001). Additionally, the improvement of administrative efficiency and the fact of a low level of mobility, which limits spill-overs (see Hoeller et al., 1996: 38), strengthen decentralised responsibility. But there exist also valuable reasons for a central assignment. Ter-Minassian (1997) discusses the effects of social risk-pooling at the central level and perceives the importance of a central guarantee of nationwide-standards for social insurance. Persson et al. (1996) supplement this position by their politico-economic point of view - they advise a strong role of the EU because of the danger of social dumping between MS. Despite this centralisation recommendation, they recognize also the dilution of rigid labour market constraints by regulatory competition, which, in turn, calls for decentralised responsibility. 
As in the general discussion of optimal decentralisation in Section I, the policy-specific normative recommendations are multifaceted and in part contradictory, as well. An unambiguous assignment is difficult to implement. This fact requires further research efforts. To begin with the presented assignment-scheme (Table IV), a respective fine-tuning is necessary. According to Shah (2002) the distinction of different government levels has to be extended by further institutional and nongovernment tiers in order to consider also privatisation effects. In this connection, the adequate delimitation of the public sector has to be discussed. This extended disaggregation holds also for the mentioned policy functions. Within R\&D, for example, there exist several topics, where the exclusive concentration on the central level seems to be more appropriate. Nuclear research could be such an example. Last, but not least, this assignment-approach has to be supported by reliable empirical conclusions. As we saw in the case of education, the opposing assignment-discussion is clarified by the strong empirical indication of a decentralised education structure (see Letelier, 2001).

Table 4

\subsection{Actual and Prospective Distribution of EU-Competences: Discussion within the European Convention ${ }^{\uparrow}$}

While the previous chapter has summarised normative recommendations for an optimal assignment of competences based on opinions of economists, this chapter focuses on the distribution in the EU. We refer mainly to documents of the debate within the European Convention. The Praesidium, the Working Group "Complementary Competences" (WG V) and indirectly also the Working Group "Subsidiarity" (WG I) dealt with the appropriate delimitation of competences between the EU and the MS.

In a first step, the Praesidium of the European Convention tried to describe the actual delimitation of competence between the EU and the MS, distinguishing between legislative and non-legislative categories (see CONV 17/02).

In a second step, they assigned concrete policy domains to the legislative category. We can classify more or less three main types of (legislative) competence conferred upon the Union: exclusive (where the internal market gets a special role), shared and complementary ones (see CONV 47/02: 6ff.).

In a third step, the Working Group V dealt with the implementation of the competence chapters in the future Treaty, with the specification of the mentioned types of competence, and especially with the role of complementary competences, which are called "supporting measures" (see CONV $375 / 1 / 02)$. It is noteworthy that there are valuable discrepancies between the Praesidium's report (CONV 47/02) and the final report of WG V (CONV 375/1/02). The latter classified development co-operation and customs co-operation as shared competences, while the former identified them as complementary ones. Furthermore, the WG V did not take care of economic policy (co-ordination) or defence, which are also classified as complementary competences by the Praesidium. Rather, they refer implicitly to the Working Groups "Economic Policy" (WG VI) and "Defence" (WG VIII). In this context we would like to draw attention to Pernice/Constantinesco (2002), who add a fourth type of competence, namely the "common co-ordination competence" (co-ordination by the Council, administrative/assisting function of the Commission or the Council, respectively), where the coordination of economic policy is included. 
In a final step, the "Draft Treaty (DT) establishing a Constitution for Europe", adopted by consensus by the Convention on 13 June and 10 July 2003, and its elaborated Title III "Union Competences" of Part I (see CONV 850/03) specifies the three categories of Union's competences and state for each category what the consequences of the Union's exercise of its competences are for the competences of the MS. The category of "supporting measures" have been renamed again - their final denomination: "supporting, coordinating or complementary action" (Article 16 DT). In contrast to the final reports of the working groups, the co-ordination of economic and employment policies has been separated out from "supporting measures" and the Common Foreign and Security Policy (CFSP) has been separated out from "shared competence" by drafting specific Articles (Art. 14-15 DT). Table V provides a respective overview. Comparing the final draft with earlier proposals of the Convention (especially with the Praesidium's report on the " Delimitation of competence between the European Union and the Member States" (CONV 47/02, May 2002), with the final report of WG V (CONV 375/1/02, November 2002) and with the Praesidium's "Draft of Articles 1 to 16 of the Constitutional Treaty" (CONV 528/03, February 2003)), remarkable shifts and amendments can be detected - in part reflecting the discussion process within the Convention and in part revealing the Praesidium's "handwriting". Without analysing these shifts and their implications by detail, we would like to emphasise critically two essential points.First, the contradictory and special case of the internal market has to be pointed out at this stage. Following the Praesidium's proposal of May 2002, the internal market has been classified as a special kind of "functional" competence for the harmonisation of legislation by the Union, where MS retain competence in some areas (see CONV 47/02: 6f). Furthermore, the February-proposal of the Praesidium classifies ensuring the four freedoms as an area of exclusive competence of the Union. At the same time the internal market, which embraces the four freedoms by definition, is allocated to the category of shared competence (see CONV 528/02: 7). In the light of these inconsistencies, this proposition has been discussed very controversially by lawyers and politicians. In March 2003, Dougan (2003: 8), for example, pointed out that this proposition is "perhaps the single most glaring legal shortcoming of the current text" and he consequently criticised that "the Praesidium approach is thoroughly inconsistent with traditional academic analysis that free movement should rightly be seen as an area of shared competence." As a consequence of this vehement protests, the final draft does not assign the four freedoms to a specific competence category anymore.

Second, similar critical remarks appear with regard to establishing competition rules necessary for the functioning of the internal market. Contrary to CONV 47/02 or to the final report of WG V, Article 12(1) DT codifies competition policy as an area of exclusive Union competence. Dougan (2003: 8) analyses the application of Articles 81 and 82 TEC and the respective decisions of the European Court of Justice and comes to the result that "neither situation can really be described as one of exclusive Union competence". The inclusion of competition policy within the areas of exclusive competence is an apparent failure to understand the current legal position and can only be explained by the tendency within the Convention to expand areas of exclusive competences.

Table 5 


\title{
3.3 Comparison of Normative Recommendations With the Actual and Prospective Distribution of Competences ${ }^{\uparrow}$
}

\author{
Preliminary remark:
}

Comparing the results from Chapter 3.1. (based on the conclusions of economists) with those from Chapter 3.2. (based on the conclusions of lawyers and politicians), we have to bear in mind that they are using a different terminology for competence matters. On the one hand, economists focus their assignment-analysis mainly on spill-overs, economies of scale and on the structure of local preferences and ask for optimal assignment and execution of various policy fields by the respective levels of government. A strict orientation on specific competence categories is not observable. On the other hand, the lawyers' analysis relies primarily on the elaborated categories, shown in Table V, and ask for the assignment of various policy tasks (mentioned in the existing Treaties, secondary legislation or Court decisions) to this specific categories. Thus, the following comparison is likely to be distorted, if the normative recommendations of economists mixed up matters of assignment and execution (like Shah 2002) or different competence classifications were used. There exist, for instance, different understandings regarding the category of exclusive competences, where economists talk about "predominant" assignment of responsibilities to the EU-level, whereas lawyers exclude any action of MS, unless explicitly admitted by the Union. Similar notions hold for the category of shared competences, where the pre-empting effects within the juridical definition are not adequately considered by economists. In this way, the legal reality of the European Union is not sufficiently reflected by economists. Furthermore, policy tasks are assigned based on the trade-off between centralisation and decentralisation, which has its foundations mainly in the nation's state analysis. A more specific application of fiscal federalism on EU competence categories, classified by lawyers and politicians, has to be strongly recommended in order to allow for more realistic and sophisticated normative-de facto-comparisons.

Comparing Table IV with Table V, we can distinguish policy domains, where the actual and prospective distribution (or more precise: "the distribution proposed by the European Convention") corresponds more or less to the normative suggestions, and functions, where remarkable discrepancies exist. To begin with the former ones, monetary policy, transport and environment seems to correspond more or less to the normative advice.

As respects regional/social policy and employment, where we found contradictory normative positions, the actual and prospective distribution does primarily correspond to the recommendations of Alesina et al. (2001) and Persson et al. (1996); in fact, also Ter-Minassian (1997) suggests a kind of shared competence in the area of social policy. However, we could ask, whether the respective responsibility of the EU should be extended in the future. Hoeller et al. (1996: 38) do not see the need for more centralised decision-making regarding social expenditures because of the low level of mobility, which limits spill-over effects from fiscally-induced migration.

The distribution by level in the area of education does correspond mainly to the advice of Persson et al. (1996). But on the one hand, education as a supporting measure does not reflect the theoretical reflections of duplication and adverse effects on the stock of human capital. On the other hand, the strong normative reasons for a sub-national involvement in this policy area are not considered in the actual Treaties. There arises the question whether the right of transnational collaboration between regions should be implemented in the future Constitution (as claimed, e.g., by Fischer, 2002: 5). 
Remarkable discrepancies between the actual and prospective distribution and the normative suggestions can be detected in the areas of agriculture and defence. On the one hand, the very extensive competence of the Community in the area of agriculture is not supported by theoretical analysis (see Hoeller et al., 1996). On the other hand, defence is one of the public goods where externalities of decisions are strongest - a central provision is therefore strongly recommended. Defence has been classified as a topic of supporting measures in CONV 47/02, while the DT does not refer anymore explicitly to Common Defence Policy. However, Persson et al. (1996: 4f) call for an appropriate institutional mechanism to enforce the centralised solution. Otherwise, simple coordination between MS fails because of free-rider effects. They explain the lack of adequate assignment to the central European level via divergences in policy preferences: "a delegation from national to European policymaking bodies of the authority to decide how to use [common] troupes [...] [seems] to be too risky at the present stage of integration" (Persson et al., 1996: 5). This explanation of Persson et al. reflects the contentious transfer of national sovereignty regarding defence and foreign policy to the EU-level and is endorsed by the collapse of CFSP during the IraqWar in spring 2003. The respective incapability of action by the Union showed on the one hand the necessity to cope definitely with the normative centralisation advice. On the other hand the vagueness and the lacking commitment of Title V TEU (see also Art. 15 DT) are demonstrated conspicuously in this way.

This brief comparison shows that adaptations of the European distribution of competences are necessary in order to reach entirely the normative benchmark. In addition to the critical preliminary remark we can ask now, how valuable is the chosen approach and how reliable is the normative benchmark for the European case. First, the normative-de facto-comparison holds more or less only under valid premises of the Theory of Fiscal Federalism and the referring experiences in existing federal states. But there are many specificities in the pre-federal structure of the EU, which limit the applicability of fiscal federalism: small budget of the EU relative to the MS, lack of provision of core public services (e.g., defence), high degree of heterogeneity in preferences for core public goods, lack of flexibility to pursue macroeconomic stabilisation objectives (see Hoeller et al., 1996: 5ff.). Thus, the sui generis character of the EU could really distort the proper adjustment of the mentioned discrepancies. Second, the necessary fine-tuning of Table IV has also to be extended to Tables V: in part, the function-level-assignment is vague and should be concretised by additional tiers of government and by a disaggregated function structure (see, e.g., Hoeller et al. 1996: 29ff., who start an attempt to analyse "spending under the umbrella of the community" function-by-function). Third, despite the normative basis, different historical, institutional, administrative or political circumstances lead to varying practices with respect to the choice of functions to be covered by each level of government (see Ter-Minassian, 1997: 6).

To sum up, to give a satisfactory answer to the question "What should and what does the European Union really do?", only a multidimensional and differentiated approach can succeed. Considering the existing discrepancies between the normative and the actual/prospective situation and taking the aforementioned critical remarks into account, it is evident to enlarge our point of view: the delineated static assignment of competences should be extended by a dynamic perspective, by a procedural approach. The following final chapter picks this perspective up and discusses it in the light of the Convention process. 


\subsection{Procedural and Institutional Suggestions}

An adjustment of the competence-distribution process should be the main feature of any reform of competences within the EU (see Henke/Perschau, 1999). As Alesina et al. (2001: 1) emphasised, "The existing EU charters fall significantly short of providing a method - let alone a detailed road map - for assigning policy prerogatives among supranational, national and local policy authorities in the continent. Providing a rationale for this is a key ingredient of any 'constitutional phase' for Europe." These statements endorse our final focus on the procedural aspects of competence allocation within the EU.

Over time public goods experience variability in their spatial characteristics. Innovations, technical adjustments and unstable local preferences change cost functions and require consequently dynamic responses within the competence distribution scheme. "Given the diversity in Member countries' interests and histories and the fact that the costs and benefits of public policies can vary widely in such a large economic area, only flexible arrangements will allow economically-sound progress in the deepening and widening of the EU" (Hoeller et al., 1996: 36). Or as Rose and Traut (2001: 3) put it, "Federalism requires permanent evaluation and readjustment according to the changing shape of a society and the new challenges that it faces as it evolves". Only a flexible process of competence distribution can guarantee proper reactions on changing general conditions. In this context, they have to consider the prerequisites of distortion-avoidance and reversibility (see Heinemann, 1995). A distribution process is distorted, when influenced remarkably by vested political interests, and irreversible, when not able to react on changing general conditions. Therefore, the development of a dynamic scheme is a special challenge for constitutional designers. The debate within the Convention has been well referring to this necessity and detected a certain trade-off between the demand for flexibility and the demand for precise delimitation (see CONV 47/02: 11). In this context, the composition of task lists or competence catalogues, respectively, is discussed controversially. On the one hand, a task list has the advantage of more transparency and clarity. On the other hand a task list included in a future Constitution, seems to be very rigid and does not correspond to the precondition of a flexible and reversible system (see COM [2002 ] 247: 22). This rigidity would be confirmed, first, when the various policy domains are assigned explicitly to the three types of competence and included with them in the future Constitution, and second, when the revision of the Constitution will be confronted with an exhausting procedure.

From the actual point of view, this fear can be confirmed. In fact, the final Draft Treaty of the Convention and the elaborated Articles 11 to 16 DT (Part I) intend to codify specific areas of the three different categories of Union competence. The DT is subdivided into four parts: (I) constitutional structure, (II) the charter of fundamental rights of the Union, (III) the policies and functioning of the Union, and (IV) general and final provisions. Although the February-proposal of the Praesidium emphasises the "Convention's wish not to establish a fixed catalogue of competences" (CONV 528/03: 15), the Articles 12, 13 and 16 indicate explicitly areas of exclusive and shared competence and areas in which the Union supports or co-ordinates actions by the MS. At first glance, the "reference in Article 13 to 'principal areas' avoids having to define in detail each area of shared competence" (CONV 528/03: 15). But it is obvious that the link to the specific provisions of Part III, which determine the extent and intensity of Union competence in each area (shared competences and supporting/co-ordinating/complementary action), does even enforce detailed regulation. The respective feared rigidity has to be evaluated in the light of the revision procedure of the Treaty establishing the Constitution as a whole and concerning the revision of the singular Parts of the Treaty. 
Draft Article IV-7 specifies the procedure for revising the Treaty establishing the Constitution. The European Council will play the crucial role in this context. After consulting the European Parliament and the Commission, the European Council shall either convene a Convention in order to examine the proposed amendments (codification of the "Convention-method") or define the terms of reference for an intergovernmental conference (if the convocation of a Convention is not justified by the extent of the proposed amendments). The European Parliament has to agree to the decision not to convene the Convention. Earlier proposals of the European Convention discussed the possibility that "certain provisions might stipulate that they may be amended by the Council or the European Council, by unanimity or qualified majority" (CONV 647/03: 13). But according to Article IV-7 amendments will only be determined if the intergovernmental conference will accept the recommendations of the Convention or decide own adaptations by "common accord" (what means, in fact, unanimous decision-making). Furthermore the amendments will only enter into force after being ratified by all the Member States.

In the light of this very exhaustive revision procedure (accordance between the European Council, the European Parliament and the Commission; convocation of a Convention; intergovernmental conference with unanimous decision-making; ratification by all Member States) and combining it with the aforementioned catalogue-discussion, the prerequisite of reversibility cannot be met sufficiently. This conclusion is endorsed by the fact that different revision procedures are not proposed for the three parts of the Treaty. Part III specifies the extent and intensity of Union competence in the case of shared competences and supporting action in a very detailed way and there applies the same revision procedure as for Part I - rigidities are built in latently.

\section{a) Shared competence and inherent flexibility}

The Member States can legislate autonomously in the field of shared competence, provided the Union has not exercised its regulatory power. Once the Union has enacted legislation, secondary law prevents the MS from adopting different rules (see Von Bogdandy/Bast, 2002: 242). If general conditions change, the abolition or the adaptation of the act of secondary law will enable to shift responsibility from the Union to the MS. "The Member States shall exercise their competence to the extent that the Union has not exercised, or has decided to cease exercising, its competence." (Article 11(2) DT). One could argue that this provision guarantees enough flexibility for proper competencereallocation. This conclusion is blurred by the fact that a qualified majority or even unanimity of the Council is required to amend or abolish a legislative act. Von Bogdandy and Bast (2002: 246f.) detect respective rigidities and refer to agricultural policy, where renationalisation-attempts and changes of the market organisation failed due to decision-making problems. They recommend to relax the conditions under which a legislative act under a shared competence can be abolished and advocate less strict majority rules for the abolition than for the adoption of the legislative act. Similar recommendations are discussed by $\mathrm{WG} \mathrm{V}$ of the Convention with regard to the design of a flexibility clause included in the future Constitution.

\section{b) Flexibility clause}

The application of Article $308 \mathrm{TEC}(14)$ is discussed controversially. The ones fear that it opens a door for unjustified centralisation and advocate its deletion. The others recommend that this article should be maintained to provide a necessary measure of flexibility in the Treaty system of competence (see CONV 375/1/02: 14). However, the final report of WG V proposes a new regulation for this article. On the one hand, they favour a specific provision enabling a qualified majority to repeal acts adopted under Article 308. This allows restoring freedom of action to the MS. Changing general conditions can be considered in this way. 
On the other hand, they recommend that unanimity in the Council should continue to be required under Article 308. Consequently, the transfer of new competences to the EU-level - in the course of the operation of the common market - is hampered remarkably in a future Union of $25 \mathrm{MS}$. Although Article 308 is not a provision, which regulates the distribution of competences ipso jure, it affects the flexibility of the distribution-process in an asymmetric way. Therefore, undesirable distortions are the consequence if the respective recommendations of WG V are included in this way in the future Constitutional Treaty. Article 17 DT (Flexibility clause) will succeed Article 308 TEC and does not refer anymore to these asymmetric majorities between adoption and repeal of acts. Nevertheless, Article 17 shows restricting elements if its provision may be used only "within the framework of the policies defined in Part III".

\section{c) Sunset legislation}

In order to respond rapidly and effectively on the demands of the real world the introduction of a new type of "delegated" act is proposed by the Working Group "Simplification" (WG IX). In this context sunset clauses are planned as control mechanisms with limited duration; "once the deadline has passed, the delegation of powers would have to be renewed by the legislator" (CONV 424/02: 11). This proposal has strongly to be approved and should be extended to the regulation of a whole competence area. Assigned competences with limited duration create continuous pressure of probation and substitute lacking inter-jurisdictional competition pressure (see Henke/Perschau, 1999). Furthermore, sunset legislation corresponds to the prerequisite of reversibility because a permanent centralisation of various functions is prevented. We can find examples for existing sunset laws in Switzerland, where the federal government's right of levying own income and value-added taxes ends after ten years and has to be confirmed by a referendum afterwards (see Eichenberger/Hosp, 2001: 99).

\section{d) Onus of proof}

In order to live up to the principle of subsidiarity and its primacy of decentralisation, proponents of centralisation should bear the onus of proof in the case of intended shifts of competences (see Färber, 2001: 133f.; Thomas, 1997: 177). From the economic point of view, this requires the verification of significant welfare-improvements due to centralisation. Otherwise no shifts should take place. Thus, it would be necessary to include a respective section in the future Constitutional Treaty. The "Protocol on the Application of the Principles of Subsidiarity and Proportionality" (see CONV 850/03: 229) picks this necessity indirectly up and recommends the composition of a "subsidiarity sheet" which should be attached to any legislative proposal of the Commission and should contain some assessment of its financial impact. Nevertheless, neither the coverage nor the binding character of this "financial impact" are already specified.

\section{e) Control mechanisms}

Not only the distribution process but also the control of competences has to be discussed regarding its efficiency effects. Following Mueller (1997: 270f.), the establishment of a special federalist court charged with the responsibility for preserving European federalism and settling jurisdictional disputes is a crucial safeguard against the overcentralisation of government activities.(15) Does the European Court of Justice in its present structure correspond to such a federalist court? The ones criticise that the Court judges too centralisation-friendly and claim therefore the institution of a new judicial body, which settles exclusively competence disputes (see Henke/Perschau, 1999). The others do not agree that the establishment of new institutions increases efficiency and/or legitimacy of dispute settlement (see Fischer, 2002: 6). 
In fact, Fischer (2002) calls for an upgrading of the Court of Justice to a real Constitutional Court and advocates ex ante monitoring of subsidiarity through this Court. Nevertheless, following the "Protocol on the Application of the Principles of Subsidiarity and Proportionality", ex ante control should be of political nature, whereby the national parliaments are involved in the context of an "early warning system". Ex post monitoring should be of judicial nature. Discussing the deficiencies of actual judicial control, we have also to pick up the debate regarding the European Court of Auditors. This Court is still dependent of Member States' agreement, when examining the accurate usage of transfers from the EU to national budgets (see Färber, 2001: 127). As this examination gives crucial information regarding the competence exercise at different European government levels, a respective revision should be debated.

\section{Summary and Concluding Remarks ${ }^{\uparrow}$}

How can policy tasks be assigned optimally to different levels of government? What for effects play a crucial role? How can we evaluate the economic effects of a decentralised government structure? What for normative recommendations hold for the delimitation of competences within the European Union? To what extent did the European Convention consider arguments of efficiency and flexibility in its competence-debate? How shall the normative benchmark be achieved and to what extent are procedural and institutional aspects decisive? The findings suggest an interesting research agenda. We can summarise the results as follows:

i. The Theory of Fiscal Federalism delivers a broad basis in order to analyse the optimal assignment of policy tasks. We have detected five different theoretical features of fiscal federalism, which affect decisively the assignment-question: consideration of local preferences, realisation of economies of scale and internalisation of externalities, interjurisdictional competition and vertical division of labour, politico-economic variables, geographical and demographic variables. These features are multidimensional and in part opposing. A concrete derivation of an overall optimal degree of decentralisation is not possible because of mixed theoretical suggestions. Pros and cons of a decentralised government structure are more or less balanced. Therefore, the adequate degree of decentralisation has to be detected task-specific, following a case-by-case approach. With regard to multifaceted interdependencies within and between the stated theoretical features, further work on the theoretical front is necessary in order to value clearer the effects of concrete decentralisation decisions.

ii. The performance of a federal structure can be evaluated by examining its effects on economic growth, on the size of the public sector, on corruption or on efficiency improvements within specific policy fields. Systematic evidence on direct relationships between economic performance and fiscal decentralisation as well as task-specific evidence is ambiguous and scarce. There is a lack of thorough cross-country econometric verifications nowadays. Thus, research has also to be enforced at the empirical front. One task is the adequate design of decentralisation - substantial investment in data collection is required in order to construct reliable and comparable indicators for federal autonomies. But it is also necessary to dig deeper into institutional details and to endorse long-term analyses.

iii. Referring to theoretical and empirical suggestions, the construction of a normative assignment scheme for the European Union is possible. Comparing the actual delimitation of EUcompetences with the normative recommendations, monetary policy, transport and environment seem to correspond more or less to the normative advice, while remarkable discrepancies arise in the fields of agriculture and defence. Discrepancies to a lesser extent can be detected in the areas of social policy, employment, industry, energy and education. However, a fine-tuning of the compared categories is undeniable in order to cope with 
different functions of policy responsibility, with additional institutional and non-government tiers, or with disaggregated policy functions. Only a multidimensional, differentiated and interdisciplinary approach can succeed. This examination is possible, if lawyers, political scientists and economists find a field of joint research. This paper should strengthen the respective co-operation attempts.

iv. In order to achieve entirely the delineated normative benchmark, remarkable changes of the actual European distribution scheme would be necessary. In the case of such incisive recommendations by the European Convention, an affirmation by the $2004 \mathrm{EU}$ Intergovernmental Conference cannot be expected (see Vaubel, 2002: 640). Nevertheless, from our point of view it is not so important what for policy functions are allocated to the different tiers of the EU at present - it is more decisive what for a kind of competencedistribution-process will be included in the future Constitutional Treaty. In fact, codified procedural aspects decide permanently future assignment and re-allocation attempts. Will they build in enough flexibility in order to react on changing general conditions? Or will the constitutional codification of precise task lists hamper the reversibility of the assignment scheme? How rigid will the revision procedure of the Treaty be? A well-elaborated design of the flexibility clause, the establishment of sunset legislation, the endorsement of bearing the onus of proof by proponents of centralisation, the development of a reversibility-guaranteeing revision procedure, or the reform of competence-dispute settlement and recognition of judicial control are necessary elements of flexible and efficient competence-allocation. As the Convention has not considered them sufficiently in its draft Constitutional Treaty, the following Intergovernmental Conference guided by the Italian Presidency, which will start after the summer recess, should pick up courage and rethink seriously the stated prerequisites of efficient and flexible competence-allocation.

\title{
References $^{\uparrow}$
}

\begin{abstract}
Alesina, A., Angeloni, I., Schuknecht, L., What does the European Union do?, NBER Working Paper 8647, Cambridge MA, December 2001.
\end{abstract}

Alesina, A., Perotti, R., Spolaore, E., Together or Separately? Issues on the Costs and Benefits of Political and Fiscal Unions, in: European Economic Review 39(3-4), April 1995, pp. 751-58.

Andersson, A. E., Hårsman, B., Quigley, J. M. [ed.], Government for the future: Unification, fragmentation and regionalism. Contribution to Economic Analysis, vol. 238, Amsterdam, New York and Oxford, 1997.

Austrian Institute for Economic Research (WIFO), Tax competition and co-ordination of tax policy in the European Union, conference proceedings; Vienna, July 13th - 14th, 1998.

Baldwin, R., Krugman, P., Agglomeration, Integration and Tax Harmonization, CEPR Discussion Paper No. 2630, November 2000.

Behnisch, A., Buettner, T., Stegarescu, D., Public Sector Centralization and Productivity Growth: A long-term View on the German Experience, conference paper, $57^{\text {th }}$ Congress of the International Institute of Public Finance, A-Linz, August 27-30, 2001.

Bird, R., Dafflon, B., Jeanrenaud, C., Kirchgässner, G., Assignment of Responsibilities and Fiscal Federalism, in: Conference Reader of the International Conference on Federalism 2002, 27-30 August 2002, St. Gallen (CH), 'Federalism in a Changing World - Learning from Each Other". 
Brennan, G., Buchanan, J. M., The Power to Tax, Analytical Foundations of a Fiscal Constitution, Cambridge University Press, Cambridge (Mass.), 1980.

Breuss, F., Eller, M., Efficiency and Federalism in the European Union - The Optimal Assignment of Policy Tasks to Different Levels of Government, Research Institute for European Affairs (IEF), Working Papers, Nr. 50, May 2003.

Bureau, D., Champsaur, P., Fiscal Federalism and European Economic Unification, in: The American Economic Review, 1992, vol. 82, n. 2, pp. 88-92.

Burrows, B. et al., Devolution or federalism? Options for a United Kingdom. Hong Kong, The Macmillan Press, 1980.

Casella, A., Frey, B., Federalism and clubs - Towards an economic theory of overlapping political jurisdictions, in: European Economic Review 36, 1992, pp. 639-646.

Cremer, J., Estache, A., Seabright, P., The Decentralization of Public Services: Lessons from the Theory of the Firm, Policy Research Working Paper 1345, Office of the Vice President, Development Economics, World Bank, Washington, D.C., 1994.

Dabla-Norris, E., Wade, P., The Challenge of Fiscal Decentralization in Transition Countries, IMF Working Paper, WP/02/103, 2002.

Davoodi, H., Zou, H., Fiscal Decentralization and Economic Growth - A Cross-Country Study, Journal of Urban Economics 1998-43, 244-257.

Dougan, M., Some Comments on the Praesidium's "Draft Treaty Establishing a Constitution for Europe", The Federal Trust for Education and Research, March 2003, http://www.fedtrust.co.uk/eu_constitution.htm .

Eichenberger, R., Hosp, G., Die institutionellen Leitplanken wirkungsvollen Föderalismus, Erfahrungen aus der Schweiz, in: Pernthaler, P., Bußjäger, P. [Hrsg.] Ökonomische Aspekte des Föderalismus, Institut für Föderalismus, Schriftenreihe Bd. 83, Innsbruck 2001, 87-104.

Elbel, R., Yilmaz, S., Concept of Fiscal Decentralization and Worldwide Overview, World Bank Institute, 2002.

European Commission: A Project for the European Union, Communication from the Commission, COM (2002) 247 final, Brussels, 2002.

European Convention - The Secretariat (2002): Description of the current system for the delimitation of competence between the European Union and the Member States, CONV 17/02.

European Convention - The Secretariat (2002): Delimitation of competence between the European Union and the Member States - Existing system, problems and avenues to be explored, CONV 47/02, Brussels, May 2002.

European Convention - The Secretariat, Preliminary draft Constitutional Treaty, CONV 369/02, Brussels, October 2002.

European Convention - The Secretariat, Final report of Working Group V, CONV 375/1/02, Brussels, November 2002.

European Convention - The Secretariat, Final report of Working Group IX, CONV 424/02, 
Brussels, November 2002.

European Convention - The Secretariat, Draft of Articles 1 to 16 of the Constitutional Treaty, CONV 528/03, Brussels, February 2003.

European Convention - The Secretariat, Part Three: General and final provisions, CONV 647/03, Brussels, April 2003.

European Convention - The Secretariat, Draft Treaty establishing a Constitution for Europe, CONV 850/03, Brussels, July 2003.

European Parliament, GD Research, Tax co-ordination in the EU-the latest position, ECON 128, 12-2001.

Färber, G., Effizienz zentralisierter und dezentralisierter Verwaltungen, in: Pernthaler, P., Bußjäger, P. [Hrsg.] Ökonomische Aspekte des Föderalismus, Institut für Föderalismus, Schriftenreihe Bd. 83, Innsbruck 2001, 105-137.

Fischer, T., (2002): Europäisches Regieren bürgernah und nachvollziehbar gestalten, Eckpunkte für eine subsidiäre und transparente Kompetenzausübung durch die EU, Centrum für angewandte Politikforschung (CAP), Konvent Spotlight 04/2002.

Fisman, R., Gatti, R., Decentralization and Corruption: Evidence Across Countries, Policy Research Working Paper 2290, World Bank, 2000.

Fornasari, F., Webb, S., Zou, H., Decentralized Spending and Central Government Deficit: International Evidence, LCSPR/DECRG, World Bank, Washington, D.C., 1999.

Frey, B., Eichenberger, R., The New Democratic Federalism for Europe: Functional, Overlapping and Competing Jurisdictions, Cheltenham 1999, Elgar.

Fuest, C., Huber, B., Tax Competition and Tax Coordination in a Median Voter Model, PublicChoice, 107(1-2), April 2001, 97-113.

Goodspeed, T.J., Tax Competition and Tax Structure in Open Federal Economies: Evidence from OECD Countries with Implications for the European Union, Centre of European Economic Research, Mannheim 1999.

Heinemann, F., Die Finanzverfassung und Kompetenzausstattung der Europäischen Union nach Maastricht: eine finanzwissenschaftliche Soll-Ist-Analyse, Schriftenreihe des Zentrum für Europäische Wirtschaftsforschung (ZEW) N. 5, Mannheim, 1995.

Hemming, R., Spahn, P., European Integration and the Theory of Fiscal Federalism, in: Bleyer, M. I., Ter-Minassian, T., Macroeconomic Dimensions of Public Finance, 1997, 110-128.

Henke, K. D., Perschau O. D., Zum Föderalismus im zusammenwachsenden Europa: Aspekte einer europäischen Sozial- und Finanzverfassung, in: Morath, K. [Hrsg.], Reform des Föderalismus, Bad Homburg 1999.

Hoeller, P., Louppe, M., Vergriete, P., Fiscal Relations within the economic union, OECD Economics Department working papers 163, 5/1996.

Hooghe, L., Marks, G., Types of Multi-Level Governance, European Integration Online Papers (EioP), Vol. 5 (2001), Nr. 11, http://eiop.or.at/eiop/texte/2001-011a.htm . 
Huther, J., Shah, A., Applying a Simple Measure of Good Governance in the Debate on Fiscal Decentralization, Working Paper N. 1894, World Bank, 1998.

Inman, R. P., Rubinfeld D. L., Fiscal Federalism in Europe: Lessons from the United States Experience, in: European Economic Review 36, 1992, pp. 654-660.

Kirchgässner, G., Effects of Fiscal Institutions on Public Finance: A Survey of the Empirical Evidence, CESifo Working Paper No. 617, 2001.

Kirchgässner, G., Schaltegger, C. A., Tiefere Staatsquote dank Föderalismus? Empirische Evidenz für einen dämpfenden Effekt, Neue Zürcher Zeitung, Nr. 190, Mo. 19.08.2002, S.7.

Kramer, H., Internationale Vergleichbarkeit der Aufwandsdaten des Staatssektors nach Aufgabenbereichen und Ebenen der Staatstätigkeit, Föderalismusdokumente Band 11, Institut für Föderalismus, Innsbruck, 2000.

Letelier, L., Effect of Fiscal Decentralisation on the Efficiency of the Public Sector. The Cases of Education and Health, conference paper, $57^{\text {th }}$ Congress of the International Institute of Public Finance, A-Linz, August 27-30, 2001.

Mueller, D. C., Federalism and the European Union: A Constitutional Perspective, Public Choice, 1997, vol. 90, pp. 255-280.

Musgrave, R. A., The Theory of Public Finance, McGraw Hill, New York, 1959.

Nelson, M. A., Searching for Leviathan: Comment and Extension, American Economic Review 77 (1987), pp. $198-204$.

Oates, W. E., Fiscal Federalism, Harcourt, Brace, Jovanovich, New York, 1972.

Oates, W. E., Searching for Leviathan: An Empirical Study, American Economic Review 75 (1985), pp. $748-757$.

Oates, W. E., Comment on "Conflicts and Dilemmas of Decentralization" by Rudolf Hommes, in: Bruno, M., Pleskovic, B. [ed.], Annual Conference on Development Economics, World Bank, 1995, pp. 351-353.

Olson, M., The Principle of "Fiscal Equivalence": The Division of Responsibilities among Different Levels of Government, American Economic Review, Papers and Proceedings 59 (2), 1969, 479-487.

Osterkamp, R., Eller, M. (2003a), How Decentralised is Government Activity? in: CESifo DICE Report, Journal for Institutional Comparisons, Vol. 1, n. 1, Ifo Institute for Economic Research, Munich, Spring 2003.

Osterkamp, R., Eller, M. (2003b), Functional Decentralisation of Government Activity, in: CESifo DICE Report, Journal for Institutional Comparisons, Vol. 1, n. 3, Ifo Institute for Economic Research, Munich, forthcoming Autumn 2003.

Pehnelt, G., Die Theorie des Fiskalföderalismus, Essay, Uni-Jena, http://www.unijena.de/ w7pege/Essays/essays.html, 1999.

Pernice, I., Constantinesco, V. (2002): Die Frage der Gemeinschaftskompetenzen aus deutscher und französischer Sicht, in: Stiftung Wissenschaft und Politik (SWP), EU im Brennpunkt, 
http://www.swp-berlin.org/produkte/brennpunkte/eu-brenn2druck.htm, (01.08.02).

Persson, T., Roland, G., Tabellini, G., The Theory of Fiscal Federalism: What does it mean for Europe?, prepared for the Conference "Quo Vadis Europe?", Kiel, June 1996.

Pigou, A. C., The Economics of Welfare, Macmillan, London, 1932.

Pitta e Cunha, P. de, Tax Harmonization, in: Pitta e Cunha, P. de, Porto, M. (Coord.), O Euro e o Mundo, January 2002, S. 45-54.

Prud'homme, R., On the Dangers of Decentralization, Policy Research Working Paper 1252. World Bank, Transportation, Water, and Urban Development Department, Transport Division, Washington, D.C., 1994.

Prud'homme, R., Comment on "Conflicts and Dilemmas of Decentralization" by Rudolf Hommes, in: Bruno, M., Pleskovic, B. [ed.], Annual World Bank Conference on Development Economics, World Bank, 1995, pp. 354-359.

Quigley, J. M., Fiscal Federalism and Economic Development - a theoretical overview, in: Andersson, A.E., Hårsman, B., Quigley, J. M. [ed.], Government for the future: Unification, fragmentation and regionalism. Contribution to Economic Analysis, vol. 238, Amsterdam, New York and Oxford, 1997, pp. 83-101.

Rose, J., Traut, J. C., Federalism and Decentralization, Perspectives for the Transformation Process in Eastern and Central Europe, George Marshall European Centre for Security Studies, 2001.

Roubini, N., Sachs, J., Political and economic determinants of budget deficits in the industrial democracies, in: European Economic Review 33, 1989, pp. 903-938.

Samuelson, P. A., The Pure Theory of Public Expenditures, in: Review of Economics and Statistics, November 1954.

Schneider, F., Wagner, A., Korporatismus im europäischen Vergleich: Förderung makroökonomischer Rahmenbedingungen?, Arbeitspapier 0015 Uni-Linz, Juli 2000.

Shah, A., Fiscal Decentralization in Transition Economies and Developing Countries - Progress, Problems and the Promise, in: Conference Reader of the International Conference on Federalism 2002, 27-30 August 2002, St. Gallen (CH), "Federalism in a Changing World - Learning from Each Other".

Sinn, H. W., How Much Europe? Subsidiarity, Centralization and Fiscal Competition, CEPR Discussion Paper 834, September 1993.

Sinn, H. W., The New Systems Competition, Basil Blackwell, Oxford 2003.

Smekal, C., Zentralisation und Dezentralisation öffentlicher Aufgabenerfüllung aus finanzwissenschaftlicher Sicht, in: Pernthaler, P., Bußjäger, P. [Hrsg.] Ökonomische Aspekte des Föderalismus, Institut für Föderalismus, Schriftenreihe Bd. 83, Innsbruck 2001, 69-76.

Tanzi, V., Fiscal Federalism and Decentralization: A Review of some efficiency and Macroeconomic Aspects, in: Bruno, M., Pleskovic, B. [ed.], Annual World Bank Conference on Development Economics, World Bank, 1995, pp. 295-316. 
Tanzi, V., On Fiscal Federalism: Issues to worry about, in: IMF, Conference on Fiscal Decentralization, Nov. 20-21, 2000, http://www.imf.org/external/pubs/ft/seminar/2000/fiscal [22.08.2002].

Ter-Minassian, T., Intergovernmental Fiscal Relations in a Macroeconomic Perspective: An Overview, in: Ter-Minassian, T., Fiscal Federalism in Theory and Practice, IMF, Washington, 1997.

Thießen, U., Fiscal federalism in Western European and selected other countries: centralization or decentralization? What is better for economic growth?, Deutsches Institut für Wirtschaftsforschung (DIW), Discussion Paper No. 224, August 2000.

Thomas, I. P., Ein Finanzausgleich für die Europäische Union? Eine allokationstheoretische und fiskalföderalistische Analyse, Tübingen 1997.

Tiebout, C. M., A Pure Theory of Local Expenditures, 1956, in: Oates, W.E. [Hrsg.], The economics of fiscal federalism and local finance, Cheltenham (UK) and Northampton (USA) 1998.

Vaubel, R., Die Politische Ökonomie des Europäischen Verfassungskonvents, in: Wirtschaftsdienst Nr. 10, 2002, 636-640.

Von Bogdandy, A., Bast, J., The European Union's vertical order of competencies: the current law and proposals for its reform, in: Common Market Law Review 39, 2002, pp. 227-268.

Von Bogdandy, A., Bast, J., Arndt, F., Handlungsformen im Unionsrecht. Empirische Analysen und dogmatische Strukturen in einem vermeintlichen Dschungel, Zeitschrift für ausländisches öffentliches Recht und Völkerrecht, Heidelberg Journal of International Law, Sonderabdruck aus Band 62, Nr. 1-2, 2002.

Von Hagen, J., Fiscal Federalism and Political Decision Structures, in: Conference Reader of the International Conference on Federalism 2002, 27-30 August 2002, St. Gallen (CH), "Federalism in a Changing World - Learning from Each Other".

Vukovich, K., Decentralisation: the economic implications of regionalism and federalism, Diplomarbeit an der Wirtschaftsuniversität Wien, 2000.

Wildasin, D., Comment on "Fiscal Federalism and Decentralization: A Review of Some Efficiency and Macroeconomic Aspects" by Vito Tanzi, in: Bruno, M., Pleskovic, B. [ed.], Annual World Bank Conference on Development Economics, World Bank, 1995, pp. 323-328.

Zax, J. S., Is There a Leviathan in Your Neighbourhood?, in: American Economic Review 79, 1989, pp. 560-567.

Zimmermann, H.; Henke, K. D., Finanzwissenschaft, München 2001, (8. Auflage).

\section{Endnotes ${ }^{\top}$}

(*) This paper is a revised version of the IEF Working Paper n. 50, May 2003 (Breuss/Eller, 2003) which was part of the IEF research project "The 2004 EU Intergovernmental Conference and the Constitutional Debate in Europe", financed by the "Jubiläums Fonds" n. 9524 of the Austrian National Bank (Oesterreichische Nationalbank). We wish to thank Stefan Griller, Angelika Hable, Rigmar Osterkamp and Dennis C. Mueller for a number of helpful comments and discussions. 
(1) See http://european-convention.eu.int/docs/sessplen/00369.en2.pdf

(2) See http://european-convention.eu.int/ArticlesTraites.asp?lang=EN

(3) See http://european-convention.eu.int/doc_wg.asp?lang=EN\&amp;Content

(4) See http://european-convention.eu.int/docs/Treaty/cv00850.en03.pdf

(5) Inspired by the EU Convention, the Austrian government has also launched an "Austrian Convention" to overhaul the Austrian Constitution (see http://www.konvent.gv.at/ ). This should also deal with Austrian federalism (Bund - Länder relationship) and rethink the adequate assignment of competences to the different federalist levels.

(6) In practice we can find examples of this governance type in Switzerland:

"Zweckverbände" (goal-oriented/functional associations) at the local level.

(7) Accordance of cost and benefit units; the "Principle of Fiscal Equivalence" has originally been developed by Olson (1969) - more details can be found in Thomas (1997) or Zimmermann/Henke (2001).

(8) See http://europa.eu.int/celex

(9) Besides the GFS, following OECD sources are used for empirical decentralisation analysis: National Accounts, Revenue Statistics, Fiscal Design Surveys Across Levels of Government.

(10) An additional evaluation of applicability of GFS as a data set for measuring FD is provided by Elbel/Yilmaz, 2002: 6f.

(11) The expenditure categories are adopted from the Government Finance Statistics Yearbook 2001 of the IMF.

(12) see http://www1.worldbank.org/publicsector/decentralization

(13) The endorsement by qualitative indicators is discussed on the World Bank's Web site on FD, see http://www1.worldbank.org/publicsector/decentralization/qualitativeindicators.htm

(14) "If action by the Community should prove necessary to attain, in the course of the operation of the common market, one of the objectives of the Community and this Treaty has not provided the necessary powers, the Council shall, acting unanimously on a proposal of the Commission and after consulting the European Parliament, take the appropriate measures."

(15) Mueller refers to four further safeguards which are necessary to maintain a federalist structure: (1) lower level geographic interests should not be represented at each level of government, (2) specific governmental functions should be assigned in the constitution to each level of government (remark: this recommendation is contrary to our aforementioned prerequisite of reversibility - see the discussion regarding competence catalogues), (3) the constitution should contain general principles for assigning new issues (see the discussion regarding the revision procedure) and (4) decisions should be made via direct democracy (in particular referendum, considering Switzerland as an example). 


\section{Table I}

\section{The Assignment of Policy Tasks to Different Levels of Government - Theoretical Survey}

\begin{tabular}{|c|c|c|c|c|c|c|}
\hline & Authors & Year & $\begin{array}{l}\text { Analysed Theoretical Features of Fiscal } \\
\text { Federalism }\end{array}$ & Major Findings (not quoted in the Text) & $\begin{array}{l}\mathbf{C} \\
(1)\end{array}$ & DEC \\
\hline \multirow{12}{*}{$\begin{array}{c}\text { Optimal } \\
\text { Conside- } \\
\text { ration } \\
\text { of Hetero- } \\
\text { geneous } \\
\text { Regional } \\
\text { Prefe- } \\
\text { rences }\end{array}$} & Färber & 2001 & $\begin{array}{l}\text { Optimal consideration of heterogeneous } \\
\text { regional preferences, development of } \\
\text { regionally diversified "production structures". } \\
\text { Advantages of "public administration } \\
\text { federalism" }\end{array}$ & $\begin{array}{l}\text { The administrative jurisdictions should have the possibility to differentiate } \\
\text { their supply regarding the existing regional preferences: efficiency gains } \\
\text { because of bundling and local information retrieval at a lower price. }\end{array}$ & & \\
\hline & Smekal & 2001 & $\begin{array}{l}\text { Optimal consideration of heterogeneous } \\
\text { regional preferences }\end{array}$ & & & \\
\hline & \begin{tabular}{|l|} 
Zimmermann \\
Henke
\end{tabular} & 2001 & Preference revealing problem & $\begin{array}{l}\text { Because of the distance of the central level to local preference revelation, } \\
\text { information, transaction, control or frustration costs could arise. Hint: fiscal } \\
\text { illusions }\end{array}$ & & \\
\hline & Thießen & 2000 & Decentralisation Theorem & & & \\
\hline & \begin{tabular}{|l} 
Andersson \\
Hårsman \\
Quigley
\end{tabular} & 1997 & $\begin{array}{l}\text { Optimal consideration of heterogeneous } \\
\text { regional preferences - linkage to the Theory of } \\
\text { Public Goods }\end{array}$ & & & \\
\hline & $\begin{array}{l}\text { Hemming } \\
\text { Spahn }\end{array}$ & 1997 & $\begin{array}{l}\text { Preference revealing problem, Model of } \\
\text { Tiebout }\end{array}$ & & $\mathrm{X}$ & \\
\hline & $\begin{array}{l}\text { Ter- } \\
\text { Minassian }\end{array}$ & 1997 & $\begin{array}{l}\text { Correspondence of expenditure priorities with } \\
\text { local preferences }\end{array}$ & $\begin{array}{l}\text { Decentralisation of expenditure responsibilities should in principle lead to } \\
\text { allocative efficiency gains. These gains may be negated by administrative } \\
\text { weaknesses at the sub-national level. }\end{array}$ & & \\
\hline & \begin{tabular}{|l|} 
Alesina \\
Perotti \\
Spolaore \\
\end{tabular} & 1995 & $\begin{array}{l}\text { Efficient provision of bundles of public goods } \\
\text { in different localities }\end{array}$ & $\begin{array}{l}\text { Differentiated bundles and costless individual mobility allow efficient } \\
\text { provision of public goods in a decentralised country }\end{array}$ & & \\
\hline & Tanzi & 1995 & $\begin{array}{l}\text { Decentralisation theorem and correspondence } \\
\text { principle. }\end{array}$ & & & \\
\hline & \begin{tabular}{|l|} 
Cremer \\
Estache \\
Seabright
\end{tabular} & 1994 & $\begin{array}{l}\text { Comparative advantages in accounting of the } \\
\text { diversity of preferences }\end{array}$ & & & \\
\hline & Oates & 1972 & $\begin{array}{l}\text { Optimal consideration of heterogeneous } \\
\text { regional preferences: decentralisation theorem, } \\
\text { correspondence principle }\end{array}$ & & & \\
\hline & Tiebout & 1956 & $\begin{array}{l}\text { Optimal consideration of heterogeneous } \\
\text { regional preferences: introducing mobility of } \\
\text { citizens. }\end{array}$ & & & \\
\hline \multirow{8}{*}{$\begin{array}{c}\text { II: } \\
\text { Realisation } \\
\text { of Economics } \\
\text { of Scale, } \\
\text { Internalisation } \\
\text { of External } \\
\text { Effects }\end{array}$} & \begin{tabular}{|l|} 
Behnisch \\
Buettner \\
Stegarescu
\end{tabular} & 2001 & $\begin{array}{l}\text { Spill-over effects between jurisdictions and } \\
\text { economic integration }\end{array}$ & $\begin{array}{l}\text { Necessity of central co-ordination in order to internalise externalities. } \\
\text { Consequently, efficiency gains and positive impacts on productivity growth } \\
\text { can be realised by centralising several policy patterns. }\end{array}$ & & \\
\hline & \begin{tabular}{|l|} 
Eichenberger \\
Hosp
\end{tabular} & 2001 & $\begin{array}{l}\text { Realisation of Economics of Scale } \\
\text { Internalisation of external effects }\end{array}$ & & & \\
\hline & Färber & 2001 & $\begin{array}{l}\text { Minimization of transaction costs and } \\
\text { internalisation of external effects }\end{array}$ & Necessity of certain central regulations in order to realise efficiency gains. & & \\
\hline & $\begin{array}{l}\text { Hooghe } \\
\text { Marks }\end{array}$ & 2001 & $\begin{array}{l}\text { Externalities and inter-jurisdictional co- } \\
\text { operation }\end{array}$ & $\begin{array}{l}\text { Distinction between two types of multi-level governance in the context of } \\
\text { dispersion of authority: } \\
\text { - Diminution of co-ordination costs by limiting the number of jurisdictions, } \\
\text { setting up multi-task, general-purpose jurisdictions with non-overlapping } \\
\text { territorial borders (Type I governance) } \\
\text { - Limitation of spill-over among jurisdictions by compartmentalising: a large } \\
\text { number of (overlapping) jurisdictions is spawned while co-ordination is } \\
\text { minimised among them (Type II governance) }\end{array}$ & & \\
\hline & Smekal & 2001 & $\begin{array}{l}\text { Realisation of Economics of Scale } \\
\text { Internalisation of external effects }\end{array}$ & & & \\
\hline & \begin{tabular}{|l} 
Schneider \\
Wagner
\end{tabular} & 2000 & $\begin{array}{l}\text { Transaction, co-ordination and negotiation } \\
\text { costs }\end{array}$ & & & \\
\hline & Vukovich & 2000 & $\begin{array}{l}\text { Realisation of Economics of Scale } \\
\text { Internalisation of external effects }\end{array}$ & & & \\
\hline & $\begin{array}{l}\text { Hemming } \\
\text { Spahn }\end{array}$ & 1997 & $\begin{array}{l}\text { Transaction, co-ordination and negotiation } \\
\text { costs }\end{array}$ & $\begin{array}{l}\text { Co-ordination can be tailored to specific functions and does not need a } \\
\text { comprehensive regional approach. A supranational government will only } \\
\text { play a catalytic role in such arrangements. }\end{array}$ & $\bar{X}$ & $\mathrm{X}$ \\
\hline
\end{tabular}




\begin{tabular}{|c|c|c|c|c|c|c|}
\hline & ||Thomas & $\mid 1997$ & 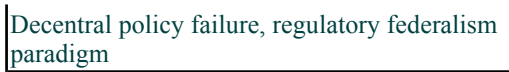 & Development of a necessary condition for centralisation decisions. & $\mathrm{X}$ & \\
\hline & Olson & 1969 & $\begin{array}{l}\text { Transaction, co-ordination and negotiation } \\
\text { costs }\end{array}$ & A decentralised pareto-optimal solution seems to be implausible. & $\mathrm{X}$ & \\
\hline \multirow{9}{*}{$\begin{array}{c}\text { III: } \\
\text { Inter- } \\
\text { juris- } \\
\text { dictional } \\
\text { Compe- } \\
\text { tition, } \\
\text { Division } \\
\text { of Labour }\end{array}$} & Von Hagen & 2002 & $\begin{array}{l}\begin{array}{l}\text { Functional Federalism: overlapping } \\
\text { jurisdictions }\end{array} \\
\end{array}$ & & & $\mathrm{X}$ \\
\hline & ||Smekal & |2001 & $\begin{array}{l}\text { Inter-jurisdictional competition and } \\
\text { enforcement of innovations Functional } \\
\text { Federalism: overlapping jurisdictions }\end{array}$ & & $\mathrm{X}$ & $\mathrm{X}$ \\
\hline & \begin{tabular}{|l|} 
Eichenberger \\
Hosp
\end{tabular} & 2001 & \begin{tabular}{|l} 
Inter-jurisdictional competition and \\
enforcement of innovations Functional \\
Federalism: overlapping jurisdictions
\end{tabular} & & & $\mathrm{X}$ \\
\hline & \begin{tabular}{|l|} 
Zimmermann \\
Henke
\end{tabular} & 2001 & Tax competition and segregation tendencies & & $\mathrm{X}$ & \\
\hline & \begin{tabular}{|l|l} 
Frey \\
Eichenberger
\end{tabular} & ||1999 & $\begin{array}{l}\text { Development of the Model of Functional, } \\
\text { Overlapping and Competing Jurisdictions }\end{array}$ & & & \\
\hline & \begin{tabular}{|l} 
Henke \\
Perschau
\end{tabular} & 1999 & $\begin{array}{l}\text { Tax competition and sub-optimal allocation of } \\
\text { resources }\end{array}$ & & $\mathrm{X}$ & \\
\hline & \begin{tabular}{|l} 
Andersson \\
Hårsman \\
Quigley
\end{tabular} & 1997 & $\begin{array}{l}\text { Comparative advantages Functional } \\
\text { Federalism: overlapping jurisdictions }\end{array}$ & & & $\mathrm{X}$ \\
\hline & Thomas & 1997 & $\begin{array}{l}\begin{array}{l}\text { Functional Federalism: overlapping } \\
\text { jurisdictions }\end{array} \\
\end{array}$ & & $\mathrm{X}$ & $\mathrm{X}$ \\
\hline & \begin{tabular}{|l} 
Cremer \\
Estache \\
Seabright
\end{tabular} & 1994 & |Comparative advantages & & & $\mathrm{X}$ \\
\hline \multirow{9}{*}{$\begin{array}{l}\text { IV: } \\
\text { Politico- } \\
\text { economic } \\
\text { Variables }\end{array}$} & \begin{tabular}{|l|} 
Eichenberger \\
Hosp
\end{tabular} & 2001 & $\begin{array}{l}\text { Enforcement of democratic control and } \\
\text { political information }\end{array}$ & & & $\mathrm{X}$ \\
\hline & ||Thießen & 2001 & \begin{tabular}{|l} 
Leviathan-behaviour, central policy failure, \\
bureaucratic quality
\end{tabular} & & & $\mathrm{X}$ \\
\hline & \begin{tabular}{|l} 
Andersson \\
Hårsman \\
Quigley
\end{tabular} & 1997 & $\begin{array}{l}\text { Increasing institutional complexity hampers } \\
\text { decision structures, } \\
\text { flexibility in local administration }\end{array}$ & & $\mathrm{X}$ & $\mathrm{X}$ \\
\hline & Thomas & ||1997 & Leviathan-behaviour, central policy failure & & & $\mathrm{X}$ \\
\hline & \begin{tabular}{|l} 
Persson \\
Roland \\
Tabellini
\end{tabular} & 1996 & $\begin{array}{l}\text { Second best effects of centralisation, effects on } \\
\text { coalition formation }\end{array}$ & & & \\
\hline & Tanzi & 1995 & Corruption, bureaucratic quality & & $\mathrm{X}$ & $\mathrm{X}$ \\
\hline & |Oates & || 1995 & Bureaucratic quality & & & X \\
\hline & Prud'homme & 1994 & Corruption, bureaucratic quality & & $\mathrm{X}$ & \\
\hline & \begin{tabular}{|l} 
Brennan \\
Buchanan
\end{tabular} & 1980 & Leviathan-behaviour, central policy failure & $\begin{array}{l}\text { As long as decentralisation spreads the power of government among } \\
\text { numerous and small lower tiers, the danger of an excessive tax burden } \\
\text { diminishes. }\end{array}$ & & $\mathrm{X}$ \\
\hline \multirow{5}{*}{$\begin{array}{c}\text { V: } \\
\text { Geo- } \\
\text { graphy } \\
\text { and } \\
\text { Demo- } \\
\text { graphy }\end{array}$} & Färber & 2001 & $\begin{array}{l}\text { Geographical distance between the } \\
\text { jurisdictions }\end{array}$ & & $\mathrm{X}$ & $\mathrm{X}$ \\
\hline & Thießen & 2000 & $\begin{array}{l}\text { Size of the jurisdiction, degree of urbanisation, } \\
\text { diversity of ethnic groups }\end{array}$ & & $\mathrm{X}$ & \\
\hline & \begin{tabular}{|l} 
Alesina \\
Perotti \\
Spolaore
\end{tabular} & 1995 & $\begin{array}{l}\text { Size of the jurisdiction and economic } \\
\text { integration; allocation of resources. } \\
\text { Geographically connected political } \\
\text { jurisdictions. }\end{array}$ & $\begin{array}{l}\text { More economic integration and freer trade should be accompanied by } \\
\text { political separatism. } \\
\text { A decentralised regime leads to a more efficient allocation of resources, by } \\
\text { limiting the resources available to those agents who have an interest in } \\
\text { distorting the economy. }\end{array}$ & & $\mathrm{X}$ \\
\hline & Prud'homme & 1995 & Degree of urbanisation & The higher the degree of urbanisation, the less difficult it is to decentralise. & & $\mathrm{X}$ \\
\hline & ||Tanzi & 1995 & Size of the jurisdiction & Break-up of the country instead of decentralisation. & & \\
\hline
\end{tabular}

(1) Normative recommendation: centralisation (C) or decentralisation (DEC), respectively. A "X" stands for unreserved responsibility of the respective level; a "x" stands for supporting/complementary involvement of the respective level. In the case of two "X", both the central and the decentral level share the responsibility. 


\section{Table II}

\section{Three Alternative Hypotheses for how Decentralisation can Indirectly Impact Growth}

\begin{tabular}{||l|l||}
\hline Hypothesis 1 & $\begin{array}{l}\text { Decentralisation increases economic efficiency in public } \\
\text { spending, therefore its dynamic effects should be growth- } \\
\text { enhancing. }\end{array}$ \\
\hline \hline Hypothesis 2 & $\begin{array}{l}\text { Decentralisation can lead to macroeconomic instability, which } \\
\text { can, in turn, inhibit growth. }\end{array}$ \\
\hline \hline Hypothesis 3 & $\begin{array}{l}\text { Developing countries have significantly different institutional } \\
\text { and economic environments than developed countries and will } \\
\text { not reap the benefits or suffer the consequences of } \\
\text { decentralisation in the same ways. }\end{array}$ \\
\hline
\end{tabular}

Source: http://www1.worldbank.org/publicsector/decentralization/growth.htm

\section{Table III}

\section{Fiscal Decentralisation and Empirical Evidence}

\begin{tabular}{|c|c|c|c|c|c|c|c|c|c|}
\hline Authors & Year & \begin{tabular}{|l|} 
Sample \\
Coverage: \\
Region \\
\end{tabular} & \begin{tabular}{|l|} 
Sample \\
Coverage: \\
Time
\end{tabular} & $\begin{array}{l}\text { Dependent } \\
\text { Variable }\end{array}$ & \begin{tabular}{|l} 
Explanatory \\
Federalism \\
Variables
\end{tabular} & Remarks & Method & $\begin{array}{l}\text { Investigated } \\
\text { Links }\end{array}$ & Major Findings \\
\hline $\begin{array}{l}\text { Alesina } \\
\text { Angeloni } \\
\text { Schuknecht }\end{array}$ & 2001 & EU-15 & $1971-2000$ & $\begin{array}{l}\text { Policy } \\
\text { intensity of the } \\
\text { EU-level }\end{array}$ & $\begin{array}{l}\text { Number of legal, } \\
\text { judiciary and other } \\
\text { non-binding acts } \\
\text { ("policy acts") per } \\
\text { government level }\end{array}$ & $\begin{array}{l}\text { Sources: TEC, TEU, } \\
\text { Steel \& Coal and } \\
\text { Euratom Treaties, } \\
\text { Celex, Court of } \\
\text { Justice website }\end{array}$ & $\begin{array}{l}\text { Counting the } \\
\text { number of the } \\
\text { acts and } \\
\text { construction of } \\
\text { relative weights } \\
\text { across policy } \\
\text { domains }\end{array}$ & $\begin{array}{l}\text { Involvement of } \\
\text { the EU in } \\
\text { policy making: } \\
\text { measures of } \\
\text { intensity by } \\
\text { policy chapter }\end{array}$ & $\begin{array}{l}\text { The data confirm that the } \\
\text { extent and the intensity of } \\
\text { policy-making by the EU } \\
\text { have increased sharply } \\
\text { over the last } 30 \text { years. } \\
\text { The allocation of EU } \\
\text { policy prerogatives is } \\
\text { partly inconsistent with } \\
\text { normative criteria for the } \\
\text { proper assignment of } \\
\text { policies at different } \\
\text { government levels. }\end{array}$ \\
\hline Oates & 1995 & $\begin{array}{l}40 \text { countries } \\
\text { (no details } \\
\text { available) }\end{array}$ & 1974-1989 & \multirow{4}{*}{\begin{tabular}{|l} 
Average \\
annual growth \\
rate of real \\
GDP per \\
capita
\end{tabular}} & \begin{tabular}{|l} 
SNG spending as \\
percentage of general \\
government \\
spending; \\
self-reliance ratio of \\
SNGs(2)
\end{tabular} & $\begin{array}{l}\text { Dissertation research } \\
\text { performed by Sang } \\
\text { Loh Kim and Oates } \\
\text { (Maryland) }\end{array}$ & & \multirow{4}{*}{$\begin{array}{l}\text { Impact of FD } \\
\text { on economic } \\
\text { growth }\end{array}$} & $\begin{array}{l}\text { Significant and robust } \\
\text { positive correlation } \\
\text { between FD and per capita } \\
\text { economic growth. } \\
\text { The self-reliance variable } \\
\text { is not itself statistically } \\
\text { significant, but its first } \\
\text { difference is. }\end{array}$ \\
\hline $\begin{array}{l}\text { Davoodi } \\
\text { Zou }\end{array}$ & 1998 & $\begin{array}{l}\text { LDCs and } \\
\text { OECD } \\
\text { countries } \\
\text { (no details } \\
\text { available) }\end{array}$ & $\begin{array}{l}\text { No details } \\
\text { available }\end{array}$ & & Degree of FD & $\begin{array}{l}\text { Surveyed in Letelier } \\
(2001)\end{array}$ & $\begin{array}{l}\text { Endogenous } \\
\text { growth model }\end{array}$ & & $\begin{array}{l}\text { In the case of developing } \\
\text { countries, they appear to } \\
\text { respond negatively - albeit } \\
\text { not significantly - to FD. } \\
\text { When the whole sample is } \\
\text { used, this negative effect } \\
\text { of FD on growth seems to } \\
\text { be more significant. }\end{array}$ \\
\hline $\begin{array}{l}\text { Schneider } \\
\text { Wagner }\end{array}$ & 2000 & $\begin{array}{l}\text { EU-14 (LU } \\
\text { is not } \\
\text { included) }\end{array}$ & 1961-1995 & & \begin{tabular}{|l} 
Degree of centralised \\
wage bargaining \\
(dummy variable: "1" \\
in the case of \\
centralised \\
bargaining)
\end{tabular} & \begin{tabular}{|l|} 
Growth regressions \\
with conflict and \\
institutional variables; \\
there is measured - \\
inter alia -the impact \\
of institutional \\
efficiency on \\
economic growth
\end{tabular} & \begin{tabular}{|l}
10 -years- \\
moving-average \\
panel with \\
Newey-West \\
estimation \\
procedures
\end{tabular} & & $\begin{array}{l}\text { The degree of centralised } \\
\text { wage bargaining shows a } \\
\text { significant (at the } 1 \% \\
\text { level) negative impact on } \\
\text { long-term economic } \\
\text { growth. Hint: impact of } \\
\text { transaction and free-rider } \\
\text { costs }\end{array}$ \\
\hline Thießen & 2000 & $\begin{array}{l}\text { EU-15, CH, } \\
\text { NO, JP, US, }\end{array}$ & $1975-1995$ & & $\begin{array}{l}\text { SNG spending as } \\
\text { percentage of general }\end{array}$ & & $\begin{array}{l}\text { Cross-sectional } \\
\text { growth }\end{array}$ & & $\begin{array}{l}\text { The analysis suggests for } \\
\text { high income countries a }\end{array}$ \\
\hline
\end{tabular}




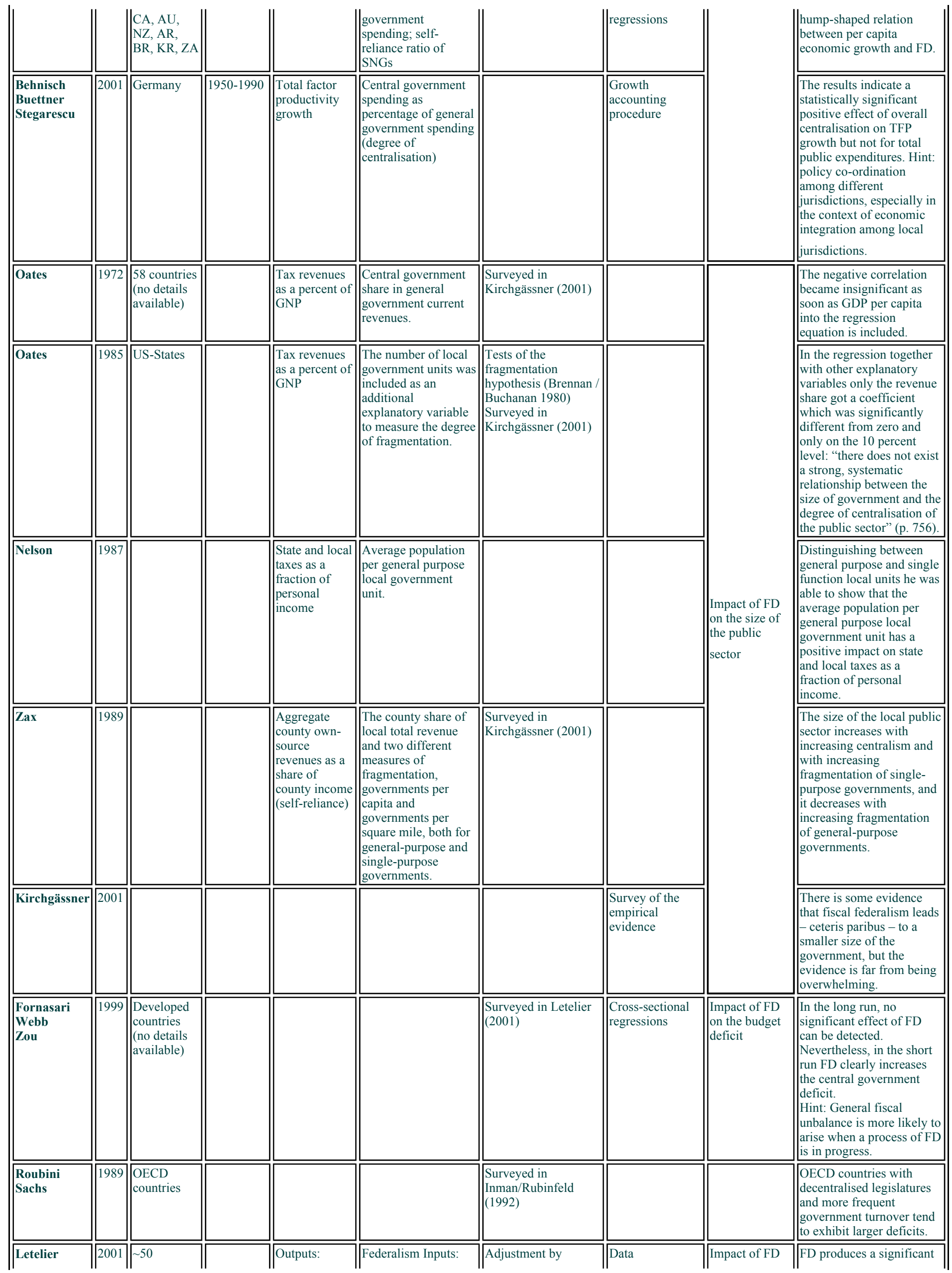




\begin{tabular}{|c|c|c|c|c|c|c|c|c|c|}
\hline & & $\begin{array}{l}\text { countries } \\
\text { (no details } \\
\text { available) }\end{array}$ & & \begin{tabular}{|l} 
"quality of \\
life" indices \\
regarding \\
education and \\
health
\end{tabular} & $\left|\begin{array}{l}\text { Average share of } \\
\text { SNG's expenditures } \\
\text { (total, education, } \\
\text { health) in the } \\
\text { respective total public } \\
\text { expenditures; self- } \\
\text { reliance ratio }\end{array}\right|$ & $\begin{array}{l}\text { environmental } \\
\text { variables that might } \\
\text { have some effects on } \\
\text { government's } \\
\text { performance }\end{array}$ & $\mid \begin{array}{l}\text { Envelopment } \\
\text { Analysis } \\
\text { (DEA) }\end{array}$ & $\begin{array}{l}\text { on the } \\
\text { efficiency of } \\
\text { education and } \\
\text { public health }\end{array}$ & $\begin{array}{l}\text { improvement on the } \\
\text { efficiency of education. } \\
\text { The quality of public } \\
\text { health services is improved } \\
\text { to a statistically less robust } \\
\text { degree. }\end{array}$ \\
\hline $\begin{array}{l}\text { Fisman } \\
\text { Gatti }\end{array}$ & \begin{tabular}{|l|}
2000 \\
\end{tabular} & \begin{tabular}{|l} 
No details \\
available
\end{tabular} & $\begin{array}{l}\text { No details } \\
\text { available }\end{array}$ & & & \begin{tabular}{|l} 
Surveyed in Letelier \\
(2001); \\
Test of \\
Prud'homme's \\
hypothesis (FD as a \\
source of corruption \\
and rent seeking)
\end{tabular} & \begin{tabular}{|l} 
Cross-country \\
regressions
\end{tabular} & $\begin{array}{l}\text { Impact of FD } \\
\text { on corruption }\end{array}$ & \begin{tabular}{|l} 
FD appears to have a \\
negative and significant \\
effect on corruption \\
Hint: improved access of \\
local elite to public \\
resources increases \\
opportunities for \\
corruption (see Dabla- \\
Norris/Wade, 2002: 4).
\end{tabular} \\
\hline $\begin{array}{l}\text { Huther } \\
\text { Shah }\end{array}$ & 1998 & \begin{tabular}{|l|}
80 countries \\
(no details \\
available)
\end{tabular} & \begin{tabular}{|l|}
$\begin{array}{l}\text { No details } \\
\text { available }\end{array}$ \\
\end{tabular} & $\begin{array}{l}\text { Composite } \\
\text { index of good } \\
\text { governance }\end{array}$ & Degree of FD & $\begin{array}{l}\text { Surveyed in Letelier } \\
(2001)\end{array}$ & \begin{tabular}{|l|} 
The index \\
contains \\
elements of \\
citizen \\
participation, \\
government \\
orientation, \\
social \\
development and \\
economic \\
management
\end{tabular} & $\begin{array}{l}\begin{array}{l}\text { Impact of FD } \\
\text { on "good } \\
\text { governance" }\end{array} \\
\end{array}$ & $\begin{array}{l}\text { They found a significant } \\
\text { and strong relationship } \\
\text { between FD and the } \\
\text { composite index of "good } \\
\text { governance". }\end{array}$ \\
\hline
\end{tabular}

(2) Self-reliance ratio of sub-national governments: average share of own revenues of lower levels in their total revenues

\section{Table IV}

\section{Delimitation of Competence within the EU - Normative Recommendations}

\begin{tabular}{|c|c|c|c|c|c|c|}
\hline Policy Domains & \begin{tabular}{|l} 
Sub- \\
Nat
\end{tabular} & NAT & \begin{tabular}{|l}
$\mathbf{E U}$ \\
$(3)$
\end{tabular} & CEN & Remarks & Authors \\
\hline \multirow{2}{*}{ External Trade } & $\mathrm{x}$ & $\mathrm{x}$ & $\mathrm{X}$ & & $\begin{array}{l}\text { Benefits \& costs international in scope; optional responsibility of SUB-NAT \& NAT for } \\
\text { provision/administration. }\end{array}$ & Shah 2002 \\
\hline & & & $\mathrm{X}$ & & $\begin{array}{l}\text { International agreements as well as uniform trade and tariff policies with non-member states. } \\
\text { Sizeable benefits from free trade at the global level. }\end{array}$ & \multirow{2}{*}{$\begin{array}{l}\text { Alesina et al. } \\
2001\end{array}$} \\
\hline Common Market & & $\mathrm{x}$ & $\mathrm{X}$ & & $\begin{array}{l}\text { Natural complement of a common external trade policy. } \\
\text { - Pro EU: Guarantee of a level playing field for free intra-area trade. } \\
\text { - Pro NAT: Exaggerated harmonisation could hamper free-area-wide competition. }\end{array}$ & \\
\hline \multirow{4}{*}{ Competition Policy } & & & $\mathrm{X}$ & & EU competence in order to promote the functioning of the internal market. & $\begin{array}{l}\text { Alesina et al. } \\
2001\end{array}$ \\
\hline & & & & $\mathrm{X}$ & Public good argument & $\begin{array}{l}\text { Eichenberger } \\
\text { Hosp 2001 }\end{array}$ \\
\hline & & & $\mathrm{X}$ & & $\begin{array}{l}\text { Transnational spill-over effects of uncompetitive behaviour or subsidies, distorting effects of } \\
\text { different national competition laws. }\end{array}$ & $\begin{array}{l}\text { Hoeller et al. } \\
1996\end{array}$ \\
\hline & & & $\mathrm{X}$ & & $\begin{array}{l}\text { Centralisation because of less risk of regulatory capture at the European than at the national } \\
\text { level (stronger competition between similar special interests). }\end{array}$ & $\begin{array}{l}\text { Persson et al. } \\
1996\end{array}$ \\
\hline \multirow{3}{*}{$\begin{array}{l}\text { Money and Finance; } \\
\text { Monetary Policy, } \\
\text { Currency, } \\
\text { Banking }\end{array}$} & & & $\mathrm{X}$ & & Independence from all levels essential. Independent Central Bank as main actor. & Shah 2002 \\
\hline & & $\mathrm{X}$ & $\mathrm{X}$ & & $\begin{array}{l}\text { - Pro EU: EoS inherent in gathering supervisory information, international spill-overs of } \\
\text { financial fragility } \\
\text { - Pro NAT: fiscal elements built into the provision of lending-last-resort } \\
\text { Other issues necessary to take into account: allocation of responsibilities in the light of the } \\
\text { OCA-Theory, integration of financial markets, co-ordination of taxation, harmonisation of } \\
\text { fiscal policies in the light of the SGP. }\end{array}$ & $\begin{array}{l}\text { Alesina et al. } \\
2001\end{array}$ \\
\hline & & & & $\mathrm{X}$ & Benefits for all citizens, homogeneity of quality and execution ("poor public goods"). & Smekal 2001 \\
\hline \multirow{2}{*}{$\begin{array}{l}\text { Industry, } \\
\text { Energy }\end{array}$} & & $\mathrm{X}$ & & & To avoid beggar-thy-neighbour policies. & Shah 2002 \\
\hline & & $\mathrm{X}$ & & & \multirow{2}{*}{$\begin{array}{l}\text { There are not provided any public goods in the classical sense: moreover, these sectoral } \\
\text { policies could hamper the completion of the internal market. }\end{array}$} & \multirow{2}{*}{$\begin{array}{l}\text { Alesina et al. } \\
2001\end{array}$} \\
\hline \multirow{2}{*}{ Agriculture } & & $\mathrm{X}$ & & & & \\
\hline & & & & & The move towards greater reliance on market forces makes the rationale for pursuing & |Hoeller et al. \\
\hline
\end{tabular}




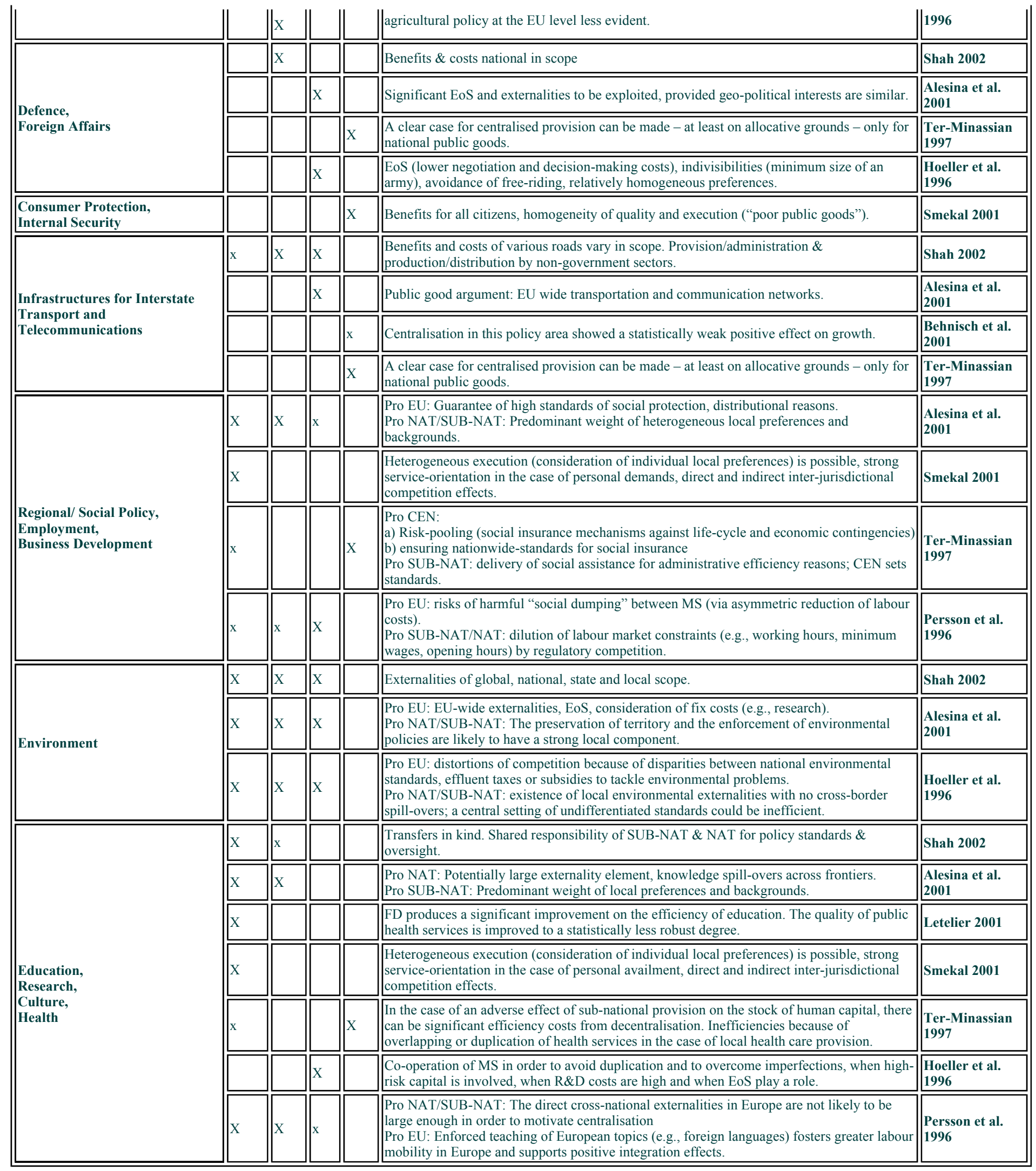

(3) SUB-NAT: sub-national (local, state, regional or provincial) level, NAT: national level (EU-Member States), EU: supranational level (European Union). In the case of no explicit distinction between national and supranational level: CEN (central level). A "X" stands for unreserved responsibility of the respective level; a "x" stands for supporting/complementary involvement of the respective level. In the case of more "X", the respective levels share the responsibility. 


\section{Table V}

\section{Delimitation of Competence within the EU - Draft Treaty (DT) establishing a Constitution for Europe, Part I, Title III}

\begin{tabular}{|c|c|c|c|c|}
\hline $\begin{array}{l}\text { CATEGORIES OF } \\
\text { COMPETENCE } \\
\end{array}$ & POLICY DOMAINS & REMARKS (Art. 11 DT) & $\begin{array}{l}\text { MS } \\
(4)\end{array}$ & $\mathbf{E U}$ \\
\hline $\begin{array}{l}\text { Exclusive competence of } \\
\text { the Union } \\
\text { (Art. } 12 \text { DT) }\end{array}$ & $\begin{array}{l}\text { a) Establishment of competition rules necessary for the functioning } \\
\text { of the internal market. } \\
\text { b) Customs union, common commercial policy, monetary policy, } \\
\text { conservation of marine biological resources. }\end{array}$ & $\begin{array}{l}\text { Only the Union may legislate and adopt legally binding acts, MS } \\
\text { may only act in such fields if authorised by the Union or for the } \\
\text { implementation of acts adopted by the Union. }\end{array}$ & & $\mathrm{X}$ \\
\hline \multirow[t]{2}{*}{$\begin{array}{l}\text { Shared competence } \\
\text { between the Union and the } \\
\text { Member States } \\
\text { (Art. } 13 \text { DT) }\end{array}$} & $\begin{array}{l}\text { Principal areas: Internal market; area of freedom, security and } \\
\text { justice; agriculture and fisheries; transport; trans-European } \\
\text { networks; energy; social policy; economic and social cohesion; } \\
\text { environment; common safety concerns in public health matters; } \\
\text { consumer protection. }\end{array}$ & $\begin{array}{l}\text { The Union and the MS shall have the power to legislate and adopt } \\
\text { legally binding acts. The MS shall exercise their competence to the } \\
\text { extent that the Union has not exercised, or has decided to cease } \\
\text { exercising, its competence. } \\
\text { The scope is specified in Part III DT. }\end{array}$ & \multirow[t]{2}{*}{$\mathrm{X}$} & \multirow[t]{2}{*}{$\mathrm{X}$} \\
\hline & $\begin{array}{l}\text { Research, technological development and space, development co- } \\
\text { operation, humanitarian aid. }\end{array}$ & $\begin{array}{l}\text { The exercise of that competence by the Union may not result in MS } \\
\text { being prevented from exercising their competence. }\end{array}$ & & \\
\hline $\begin{array}{l}\text { Co-ordination of economic } \\
\text { and employment policies } \\
\text { (Art. } 14 \text { DT) }\end{array}$ & & $\begin{array}{l}\text { The Union shall adopt measures to ensure coordination of the } \\
\text { economic and employment policies of the MS, in particular by } \\
\text { adopting guidelines for these policies. The MS shall coordinate their } \\
\text { economic policies within the Union. }\end{array}$ & $\mathrm{X}$ & $\mathrm{x}$ \\
\hline $\begin{array}{l}\text { Common foreign and } \\
\text { security policy } \\
\text { (Art. } 15 \text { DT) }\end{array}$ & & $\begin{array}{l}\text { MS shall actively and unreservedly support the Union's CFSP in a } \\
\text { spirit of loyalty and mutual solidarity and shall comply with the acts } \\
\text { adopted by the Union in this area. They shall refrain from action } \\
\text { contrary to the Union's interests or likely to impair its effectiveness. }\end{array}$ & $\mathrm{x}$ & $\mathrm{X}$ \\
\hline $\begin{array}{l}\text { Supporting, coordinating } \\
\text { or complementary action } \\
\text { (Art. } 16 \mathrm{DT})\end{array}$ & $\begin{array}{l}\text { Industry; protection and improvement of human health; education, } \\
\text { vocational training, youth; culture; sport; civil protection. }\end{array}$ & $\begin{array}{l}\text { The Union shall have competence to carry out actions to co- } \\
\text { ordinate, supplement or support the actions of the MS, without } \\
\text { thereby superseding their competence in these areas. } \\
\text { Legally binding acts adopted by the Union cannot entail } \\
\text { harmonisation of Member States' laws or regulations. } \\
\text { The scope is specified in Part III DT. }\end{array}$ & $\mathrm{X}$ & $\mathrm{X}$ \\
\hline $\begin{array}{l}\text { Member State's } \\
\text { Competence } \\
\text { (Art.9(2) DT) }\end{array}$ & & $\begin{array}{l}\text { Competencies not conferred upon the Union in the Constitution } \\
\text { remain with the Member States. }\end{array}$ & $\mathrm{X}$ & \\
\hline
\end{tabular}

(4) MS: EU-Member States, EU: supranational level (European Union). A "X" stands for unreserved responsibility of the respective level; a "x" stands for supporting/complementary involvement of the respective level. In the case of more "X", the respective levels share the responsibility.

Source: CONV 850/03, July 2003 


\section{Figure 1}

\section{Derivation of an optimal degree of decentralisation}

The optimal degree of decentralisation

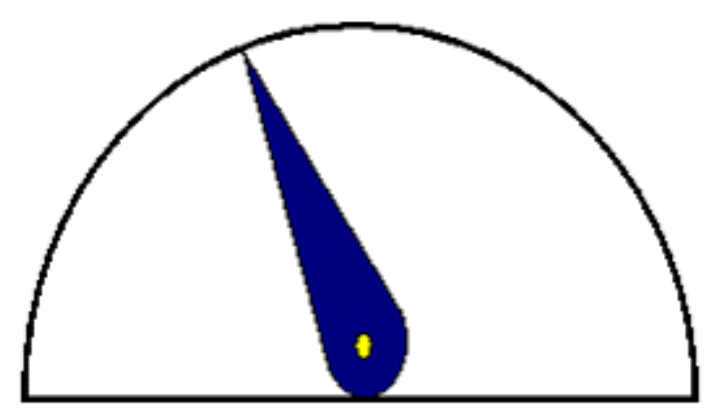

Full decentralisation

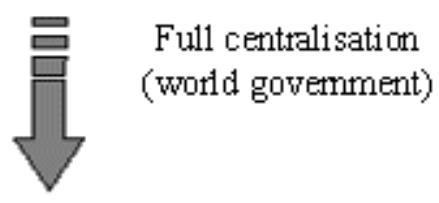

Basic trade-off:

consider ation of local preferences vs. realisation of sale effects

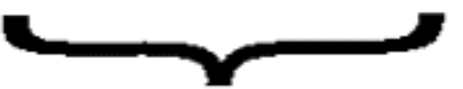

Crucial issue:

idertification of the appropriate level of decentralisation for each kind of activity 


\section{Figure 2}

\section{Economic Growth vs. Degree of Fiscal Decentralisation}

Figure II: Ecomomic Growth w. Degree of Fiscal Decentralisation

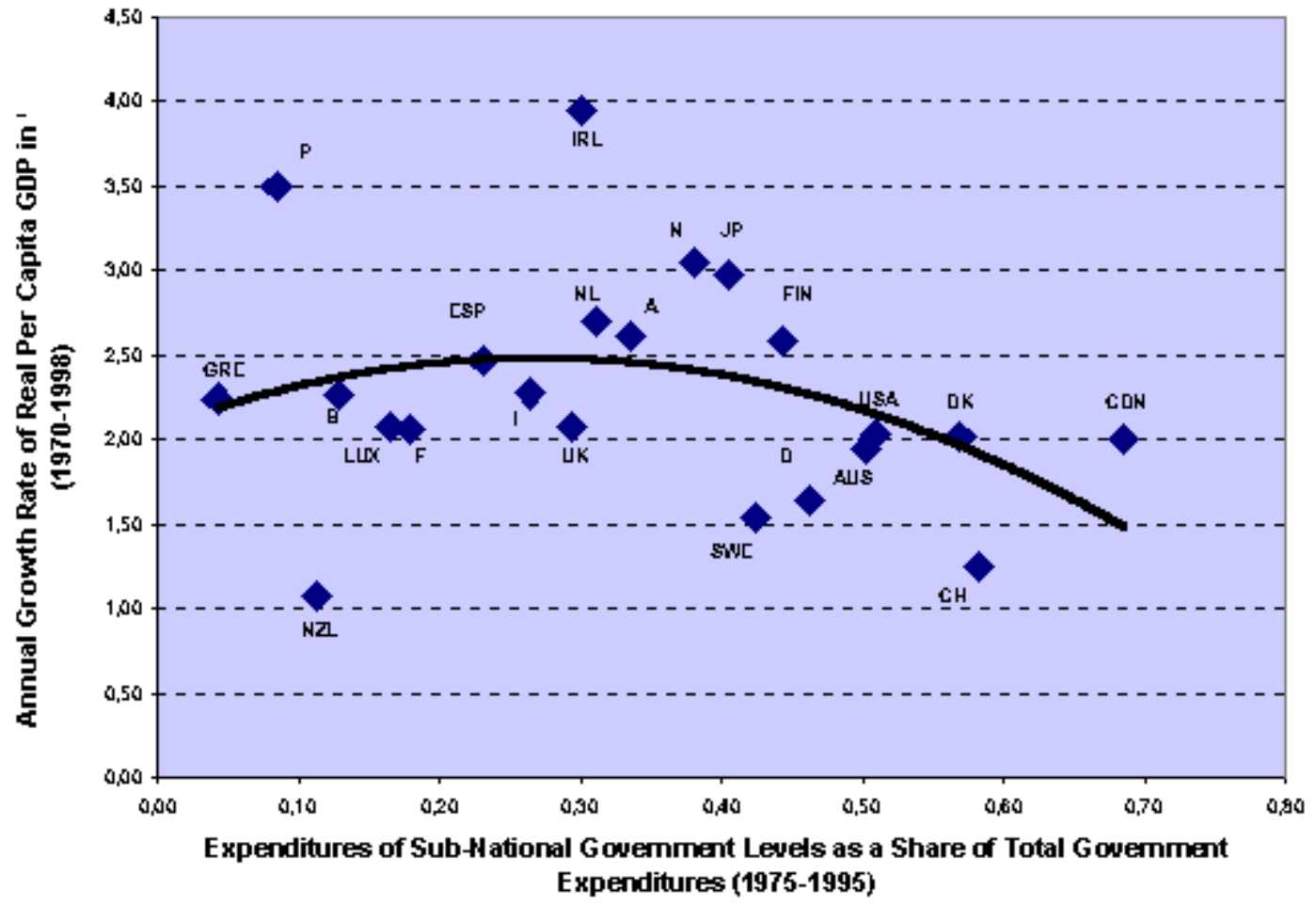

Source: Thießen (2000); Data: IMF (International Financial Statistics and GFS) 